\title{
10. PETROLOGY, GEOCHEMISTRY, AND MINERALOGY OF THE EARLY CRETACEOUS EVOLVED N-MORB FROM SITES 765 AND 766, EASTERN INDIAN OCEAN ${ }^{1}$
}

\author{
Akira Ishiwatari ${ }^{2}$
}

\begin{abstract}
The Early Cretaceous basaltic rocks obtained from Sites 765 and 766 in the eastern Indian Ocean floor were mostly iron-rich normal mid-ocean ridge basalts (N-MORB), which were derived from a depleted mantle source having strongly light rare earth element (LREE)-depleted rare-earth patterns and a high titanium/zirconium ( $\mathrm{Ti} / \mathrm{Zr}$ ) ratio. Basaltic rocks in the upper part of the Site 765 basement section include megacrysts and gabbroic fragments of widely varying mineral chemistry. These megacrysts range from $\mathrm{An}_{90}$ plagioclase, including highly magnesian basaltic glass coexisting with augite of $\mathrm{Mg \#}(=100 \mathrm{Mg} /[\mathrm{Fe}+\mathrm{Mg}])$ at 85 , to $\mathrm{An}_{50}$ plagioclase coexisting with hypersthene. This varying mineralogy of megacrysts and gabbroic fragments indicates that a considerable degree of fractional crystallization took place in the magma chamber. The unusual negative correlation between incompatible elements (e.g., $\mathrm{TiO}_{2}$ ) and $\mathrm{FeO}^{*} / \mathrm{MgO}$ observed among Site 765 basement basalts and fresh volcanic glasses suggest source-mantle heterogeneity in terms of $\mathrm{FeO} / \mathrm{MgO}$. Strontium isotope ratios $\left({ }^{87} \mathrm{Sr}{ }^{86} \mathrm{Sr}\right)$ of the basaltic rocks from both sites are between 0.7027 and 0.7033 and are comparable to those of mid-Indian Ocean ridge basalts (MIORB).

The basalt pebbles encountered in the sedimentary section may have been transported from the basement highs nearer the Australian continent and include basaltic compositions ranging from primitive N-MORBs to evolved enriched(E)MORBs. Their mantle source was not as depleted as that of the basement basalts. These rocks may be the products of earlier volcanism that took place during the rifting of the Australian continent.
\end{abstract}

\section{INTRODUCTION}

This chapter describes the petrography, geochemistry, and mineral chemistry of the basaltic rocks that constitute one of the oldest basement regions of the floor of the eastern Indian Ocean off the northwestern margin of Australia. The basalt pebbles encountered in the turbidites of the overlying Cretaceous and Tertiary sediments also were studied in some detail, because they were derived from areas nearer the Australian passive margin and thus could provide information about volcanism associated with early rifting events prior to ocean floor spreading.

Chemical and isotopic heterogeneities having a scale of 100 $\mathrm{km}$ in the mantle along ocean ridges were established in the $1970 \mathrm{~s}$ (Wood et al., 1979, and references therein), and a global anomaly was recognized in the 1980s (Dupré and Allègre, 1983; Hart, 1984). The present Mid-Indian Ocean Ridge (MIOR) lies mostly in this "Dupal anomaly" that dominates the Southern Hemisphere. The isotopic difference between MIORB and the other MORBs in the Pacific and Atlantic oceans has been explained by the contamination of the depleted N-MORB source in a shallow mantle with the deeper, enriched Dupal material. The anomaly of MIORBs is especially distinct in the area around the triple junction $\left(70^{\circ} \mathrm{E}, 26^{\circ} \mathrm{S}\right)$ (Price et al., 1986).

The presence of this global isotopic anomaly and the two-street chemical layering model of the mantle (MORB source/Dupal material) has been challenged by Holness and Richter (1989), who postulated smaller-scale, but widespread, heterogeneity in the mantle. These authors documented that the trace-element and isotope chemistries of MORBs correlate well with the spreading rate of the ridge in the Atlantic and Pacific oceans; the lanthanum/samarium (La/Sm) and ${ }^{87} \mathrm{Sr} /{ }^{86} \mathrm{Sr}$ ratios decrease with spreading rate. This correlation may result from a mantle composed of

\footnotetext{
${ }^{1}$ Gradstein, F. M., Ludden, J. N., et al., 1992. Proc. ODP, Sci. Results, 123: College Station, TX (Ocean Drilling Program).

${ }^{2}$ Department of Earth Sciences, Faculty of Science, Kanazawa University, Kanazawa 920, Japan.
}

a fine patchwork of the enriched and depleted segments, perhaps on a scale of $1 \mathrm{~km}$ or smaller, and selective melting of the enriched segments in a slow-spreading environment.

The evolved N-MORBs of Early Cretaceous age obtained from the basement sections of Sites 765 and 766 constrain these global and local mantle heterogeneities, as discussed above.

\section{DESCRIPTION AND RESULTS}

\section{Lithostratigraphy of the Drilled Basement Section}

The lithostratigraphy of the basaltic basement drilled at Site 765 is presented in Figure 1. The basement is composed of pillow lava $(54 \%)$, massive lava flows $(28 \%)$, basaltic breccia $(8 \%)$, hyaloclastite $(6 \%)$, and a diabase sill(?) $(4 \%)$. The basement sections of Holes $765 \mathrm{C}$ and $765 \mathrm{D}$ are divided into 24 lithologic units, which were based primarily on visual differences in the core, but in some cases were divided by a geochemical change in a visually homogeneous lithology.

The sediment/basement interface was recovered from Hole $765 \mathrm{C}$ at a depth of $935 \mathrm{mbsf}$, where red calcareous clay of early Berriasian or late Valanginian age conformably overlies the altered green hyaloclastite (Ludden, Gradstein, et al., 1990, p. 184, Fig. 89). The matrix of the hyaloclastite is white calcite crystals with some red clay. The hyaloclastite is only $10 \mathrm{~cm}$ thick and is underlain by a thick pile of pillow lavas.

The sediment/basement interface was not recovered in Hole $765 \mathrm{D}$, which is a maximum of $100 \mathrm{~m}$ away from Hole $765 \mathrm{C}$. The upper $50 \mathrm{~m}$ of the basement section (i.e., from Unit 1 to Unit 3) consists of massive lava flows, with intercalations of breccia and hyaloclastite. The lower $200 \mathrm{~m}$ is composed mainly of pillow lavas, with intercalations of at least five massive lava flows and at least five breccia/hyaloclastite sequences. Unit 7 is distinctly coarser-grained than others and may be a diabase sill (or a lava flow) about $10 \mathrm{~m}$ thick, although the upper and lower contacts were not recovered.

The basement basalts of Hole $765 \mathrm{C}$ and in the upper $50 \mathrm{~m}$ of Hole $765 \mathrm{D}$ include many megacrysts (as defined by Donaldson and Brown, 1977) of plagioclase and clinopyroxene, as well as 


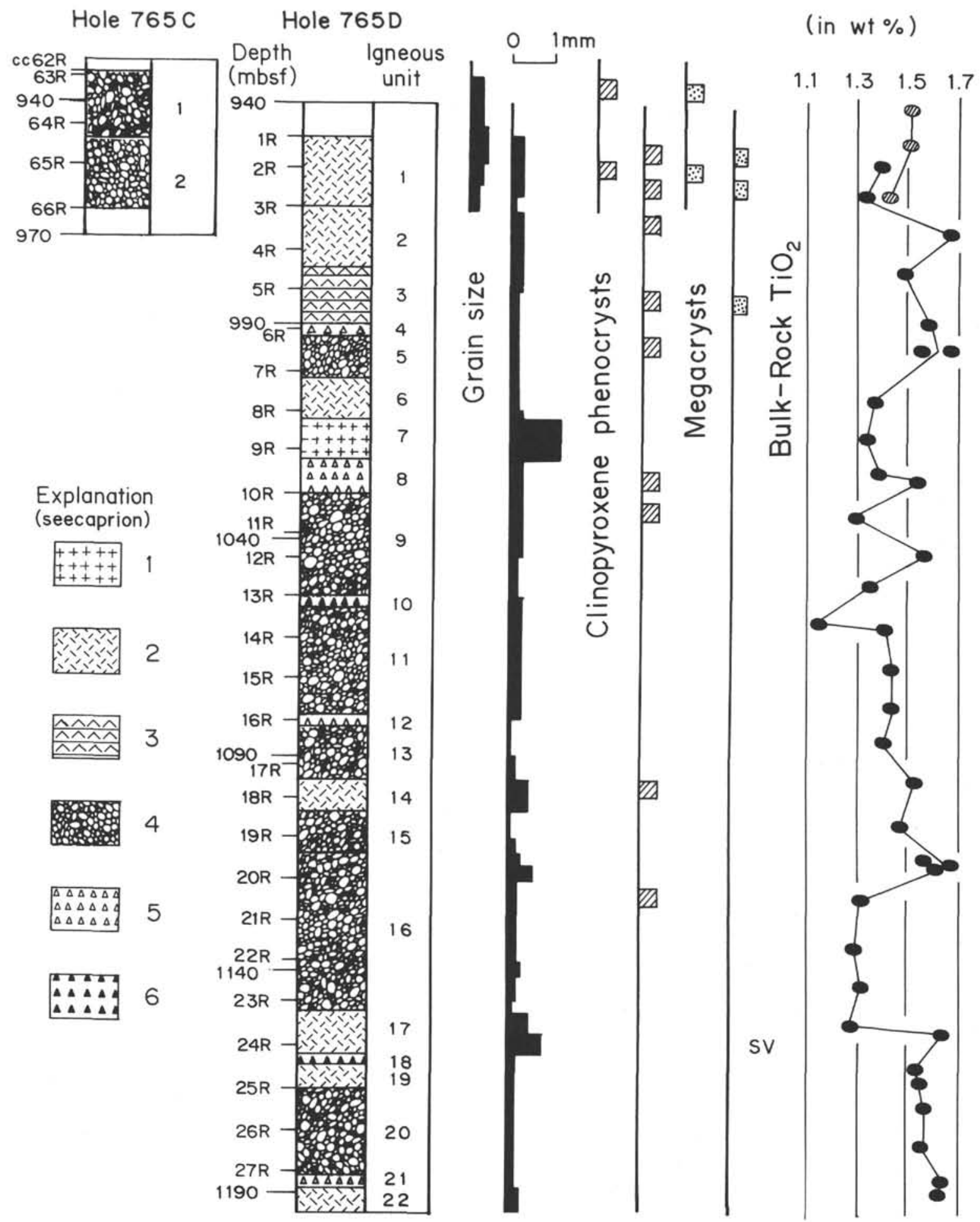

Figure 1. Lithostratigraphy of Site 765 basement. Symbols (1) diabase sill, (2) sheet flow, (3) alternation of breccia and sheet flow, (4) pillow lava, (5) hyaloclastite, and (6) breccia. "Sv" signifies the occurrence of segregation vesicles at the level. Bulk rock $\mathrm{TiO}_{2}$ contents are based on shipboard XRF analyses (see Init. Repts. volume for data).

fragments of gabbroic rocks up to $1 \mathrm{~cm}$ in diameter (see Ludden, Gradstein, et al., 1990; p. 189, Fig. 95 and p. 190, Fig. 97). The megacrysts and gabbroic fragments from Hole 765D are of a relatively evolved composition, as indicated by the occurrence of hypersthene-bearing gabbro fragments, but those from Hole $765 \mathrm{C}$ are primitive and bear highly magnesian basaltic melt inclusions (Plate 1).

The basement rocks are locally fresh despite their Early Cretaceous age. Fresh glass having an obsidian luster in some cases is preserved in the chilled rim of a pillow lava or in the fragments 
of green hyaloclastite (see Ludden, Gradstein, et al., 1990; p. 184, Fig. 90). In most cases, however, this glass was replaced by green clay, zeolite, and calcite. Alteration halos ( 2 or $3 \mathrm{~cm}$ wide) have developed along joints in pillow lavas or massive lava flows throughout the basement section (see Ludden, Gradstein, et al., 1990; pp. 196-197, Figs. 100-103 and Adamson et al., this volume).

Many pebbles of basaltic rocks were recovered from the conglomerate beds in the sedimentary section. These are associated with a large number of sandstone, mudstone, limestone, and ironstone pebbles. The age of the conglomerate beds that contain these basaltic pebbles ranges from Late Cretaceous to Quaternary. However, the majority occur in a Miocene turbidite sequence occupying more than one-half the thickness of the sedimentary section. Some pebbles are in-situ with molded contacts, but others occur as "drill breccia." These dropped from the wall of the drill hole and then were accidentally recovered later on top of a subsequent core. Including these "drill breccia," more than 100 basalt pebbles were found from 44 levels. Most pebbles are 2 to $5 \mathrm{~cm}$ in diameter and subangular to well-rounded. The largest pebble was $14 \mathrm{~cm}$ long and more than $6 \mathrm{~cm}$ wide.

The lithostratigraphy of Site 766 "basement" is presented in Figure 2. The lowermost part of the sedimentary section is composed of massive black siltstone of Valanginian age, with pyrite nodules and wood fragments. The basaltic rocks forming the acoustic basement are intrusions cutting the siltstone. Units 1,2 , and 3 are gently inclined sills having a thickness of $2.5,0.4$, and $2.0 \mathrm{~m}$, respectively. These sills have fine-grained chilled margins, and the adjacent siltstone was thermally hardened for $10 \mathrm{~cm}$ from the contact. The interface between Unit 2 and the sediments is

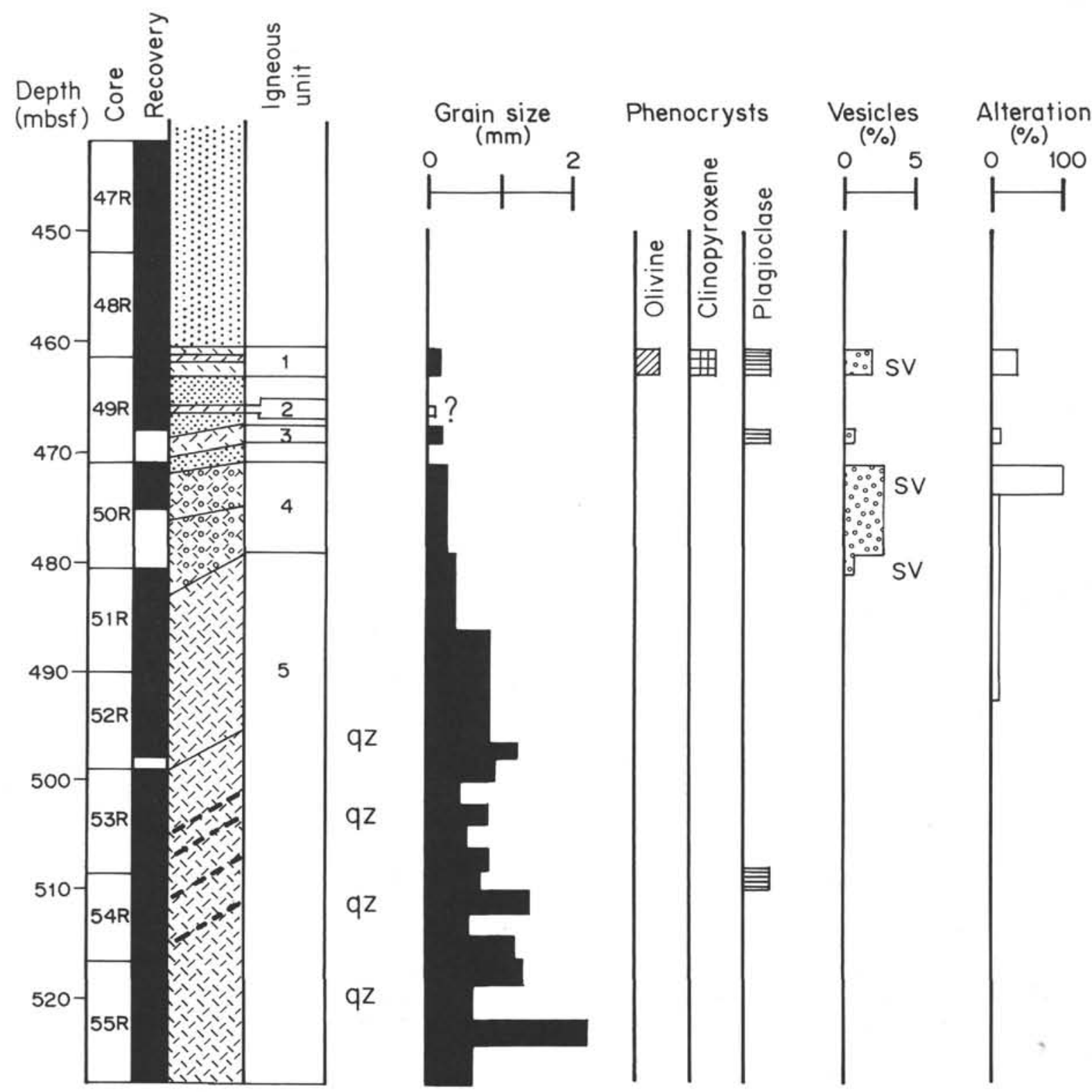

Figure 2. Lithostratigraphy of Site 766 "basement." Basalt (Units 1 through 3) and diabase (Units 4 and 5) were intruded into black siltstone of Valanginian age (dots). Units 1 through 4 may be gently inclined sills, while Unit 5 may represent steeply dipping dikes. Unit 4 is vesicular. Solid line in Unit 5 indicates a chilled margin, and thick broken lines represent gabbroic layers. "qz" represents the occurrence of euhedral igneous quartz in the mesostasis; "sv" signifies that of segregation vesicles. 
sinuous. Unit 4 is distinguished from the other units by its highly vesicular nature. This unit may also be a sill, although its lower contact was not recovered. The lowest unit of Hole $766 \mathrm{~A}$ is a medium- to coarse-grained diabase body (Unit 5) at least $47 \mathrm{~m}$ thick. All internal features of Unit 5 (such as cooling boundaries, coarse-grained gabbroic layers as thick as $10 \mathrm{~cm}$, and parallel platy joints at 2 - or $3-\mathrm{cm}$ intervals) are consistently inclined at $50^{\circ}$ to $60^{\circ}$ (see Ludden, Gradstein, et al., 1990; p. 318, Fig. 47; p. 322, Fig. 50; and p. 333, Fig. 72), suggesting that the diabase body is a steeply inclined dike. Units 1,2, and the upper part of 4 have been strongly altered, while the other parts are relatively fresh. However, no glass was preserved at this site.

\section{Petrographic Characteristics of the Basaltic Rocks}

The basaltic rocks forming the basement of Site 765 are mostly aphyric. Grain size of the groundmass, defined by the average length of the 10 largest plagioclase laths in a thin section, ranges from $0.1 \mathrm{~mm}$ in the pillow margins to $0.4 \mathrm{~mm}$ in the pillow cores, and is 0.6 to $0.8 \mathrm{~mm}$ in a thick massive flow, and as large as 1.2 $\mathrm{mm}$ in the diabase sill. Plagioclase, clinopyroxene, and olivine occur as phenocrysts. The abundance of clinopyroxene, the scarcity of olivine, and the absence of spinel as phenocryst are unusual for MORBs and suggest evolved magmas. The evolved nature of the magma is also suggested by the occurrence of segregation vesicles (Anderson et al., 1984; Sato, 1978). The segregated magma is of Fe-Ti basalt composition, and is now composed of quench crystals of ilmenite, $\mathrm{Fe}-\mathrm{Ti}$ augite, and plagioclase (Plate 1, Fig. 1).

As mentioned in the lithostratigraphy section, a number of megacrysts and gabbroic fragments were found in the upper $50-\mathrm{m}$ section of the basement at Site 765. Of their constituent minerals, plagioclase is abundant, clinopyroxene common, and orthopyroxene rare. The plagioclase megacrysts exhibit remarkable concentric zoning and dense accumulations of tiny glass inclusions of about $10 \mathrm{~mm}$ in diameter occur in some zones (Plate 1, Fig. 2). The lavas of the upper part of Hole 765D tend to bear megacrysts and gabbroic fragments made of low-An plagioclase, low-Mg clinopyroxene, and rare orthopyroxene; these lavas may have sampled higher parts of a solidifying magma chamber than those in Hole $765 \mathrm{C}$, which contain megacrysts and gabbroic fragments with plagioclase as calcic as $\mathrm{An}_{90}$ and clinopyroxene having a $\mathrm{Mg \#}$ as high as 85 .

The petrographic characteristics of Site 766 basement are diverse (Fig. 2). Unit 1 is moderately phyric, with plagioclase, clinopyroxene, and olivine phenocrysts, and is clearly distinguished from the other aphyric units. Unit 4 is highly vesicular. These vesicles are filled with green clay minerals or calcite. The coarse-grained diabase or gabbro of Unit 5 bears euhedral or subhedral quartz as the latest crystallization product in its mesostasis. This indicates that the magma was silica-saturated and evolved.

\section{Bulk Rock Chemistry of the Basaltic Rocks}

Five pebbles and 39 basement rocks of Site 765, as well as one pebble and 13 "basement" rocks of Site 766 , were analyzed for major and trace elements in the shipboard XRF laboratory (see Ludden, Gradstein, et al., 1990 for these data). In addition, the fresh volcanic glass samples were analyzed by an energy-dispersive X-ray analyzer EDAX-9100 on the Akashi a-30A SEM of the Faculty of Science, Kanazawa University. Natural minerals and quenched glass beads of molten Geological Survey of Japan (GSJ) standard rocks were used as standards.

The average chemical composition of Site 765 basement closely resembles that of typical MORBs in respect to low $\mathrm{P}_{2} \mathrm{O}_{5}$ and moderate $\mathrm{TiO}_{2}(1.5 \mathrm{wt} \%)$, while being slightly poorer in $\mathrm{MgO}$ and richer in $\mathrm{FeO}^{*}$ (Table 1). The latter features indicate that the
Table 1. Representative bulk-rock chemistry of the basaltic rocks from Sites 765 and 766 .

\begin{tabular}{|c|c|c|c|c|c|}
\hline \multirow[b]{2}{*}{ Unit } & \multicolumn{2}{|c|}{ Site 765} & \multicolumn{3}{|c|}{ Site 766} \\
\hline & Basement & Pebble & Unit 1 & Unit 3 & Units 4,5 \\
\hline No. ${ }^{a}$ & $38(9)$ & $1(1)$ & 1(1) & $1(1)$ & $11(3)$ \\
\hline \multicolumn{6}{|c|}{ Major elements (in oxide wt\%) } \\
\hline $\mathrm{SiO}_{2}$ & 50.53 & 49.40 & 47.41 & 50.05 & 50.60 \\
\hline $\mathrm{TiO}_{2}$ & 1.50 & 1.15 & 2.97 & 1.10 & 1.79 \\
\hline $\mathrm{Al}_{2} \mathrm{O}_{3}$ & 14.79 & 19.37 & 16.88 & 15.15 & 13.34 \\
\hline${ }^{\mathrm{b}} \mathrm{FeO}$ & 11.08 & 9.17 & 15.88 & 9.38 & 13.77 \\
\hline $\mathrm{MnO}$ & 0.21 & 0.14 & 0.15 & 0.16 & 0.23 \\
\hline $\mathrm{MgO}$ & 6.82 & 6.96 & 5.46 & 7.82 & 6.86 \\
\hline $\mathrm{CaO}$ & 12.03 & 10.77 & 7.22 & 13.45 & 10.66 \\
\hline $\mathrm{Na}_{2} \mathrm{O}$ & 2.35 & 2.85 & 4.01 & 2.77 & 2.59 \\
\hline $\mathrm{K}_{2} \mathrm{O}$ & 0.59 & 0.15 & 0.09 & 0.06 & 0.05 \\
\hline $\mathrm{P}_{2} \mathrm{O}_{5}$ & 0.10 & 0.04 & 0.23 & 0.06 & 0.11 \\
\hline Total & 100.00 & 100.00 & 100.00 & 100.00 & 100.00 \\
\hline${ }^{c}$ LOI & 1.12 & 3.64 & 2.26 & 1.10 & 0.78 \\
\hline $\mathrm{FeO}^{*} / \mathrm{MgO}$ & 1.62 & 1.32 & 2.91 & 1.20 & 2.01 \\
\hline
\end{tabular}

Minor elements (in ppm)

$\begin{array}{lrrrrr}\mathrm{Rb} & 10 & 1 & <1 & <1 & <1 \\ \mathrm{Ba} & 11 & 12 & 10 & <1 & 6 \\ \mathrm{Nb} & 2 & 2 & 5 & 2 & 3 \\ \mathrm{Ce} & 11 & 5 & 24 & 6 & 12 \\ \mathrm{Sr} & 89 & 233 & 129 & 107 & 77 \\ \mathrm{Zr} & 83 & 64 & 167 & 56 & 94 \\ \mathrm{~V} & 378 & 250 & 617 & 303 & 427 \\ \mathrm{Y} & 36 & 23 & 46 & 26 & 42 \\ \mathrm{Cr} & 194 & 607 & 160 & 315 & 118 \\ \mathrm{Ni} & 75 & 360 & 61 & 70 & 61 \\ \mathrm{Cu} & 71 & 81 & 92 & 116 & 95 \\ \mathrm{Zn} & 104 & 85 & 155 & 84 & 114 \\ \mathrm{Co} & 53 & 55 & 55 & 47 & 55 \\ \mathrm{Sc} & 47 & 40 & 51 & 49 & 50 \\ \mathrm{Hf} & 2.4 & 1.7 & 3.7 & 2.0 & 2.5\end{array}$

Rare earth elements (in chondrite-normalized values)

\begin{tabular}{lrcccr}
$\mathrm{La}$ & ${ }^{\mathrm{d}} 5.6$ & 4.8 & 11.6 & $<4$ & 6.2 \\
$\mathrm{Ce}$ & 8.1 & $<7$ & 15.3 & $<7$ & 9.3 \\
$\mathrm{Sm}$ & 13.9 & 8.7 & 19.1 & 8.7 & 15.2 \\
$\mathrm{Eu}$ & 13.7 & 9.8 & 17.0 & 8.8 & 13.9 \\
$\mathrm{Yb}$ & 15.2 & 8.8 & 17.3 & 9.1 & 19.3 \\
$\mathrm{Lu}$ & 13.9 & 8.5 & 16.0 & 8.8 & 18.2 \\
\hline
\end{tabular}

Note: The major-element oxide values are normalized to total $100 \%$. Co, Sc, Hf, and REEs were analyzed using INAA method, and the other elements using shipboard XRF analysis.

a Number of XRF and INAA (in parentheses) analyses averaged.

b $\mathrm{Total} \mathrm{Fe}$ as $\mathrm{FeO}$.

c $\mathrm{LOI}=$ loss on ignition.

d 3.2 to 4.5 in the upper part and 6.0 to 7.0 in the lower part of the basement section.

magma was evolved. The average $\mathrm{K}_{2} \mathrm{O}$ and rubidium contents are distinctly higher than N-MORB, but these contents are positively correlated with the loss on ignition, and thus may have been introduced during alteration. The chemical composition of the basaltic rocks is relatively homogeneous throughout the whole basement section of Site 765 (dots in Figs. 1 and 3A), which consists of several repetitions of slightly evolved and primitive lavas superimposing each other. Systematic downhole differentiation is absent.

The basaltic pebbles in the sedimentary section of Site 765 have a highly diverse chemistry. These pebbles include depleted $\mathrm{N}$-MORBs that are richer in chromium and nickel than the most primitive basalt of the basement, T- or E-MORBs with LREE/ HREE ratios larger than chondrite and with clinopyroxenes having an alkalic differentiation trend (see next section), and the oceanic andesite having $54 \mathrm{wt} \% \mathrm{SiO}_{2}$. Note that even the most 


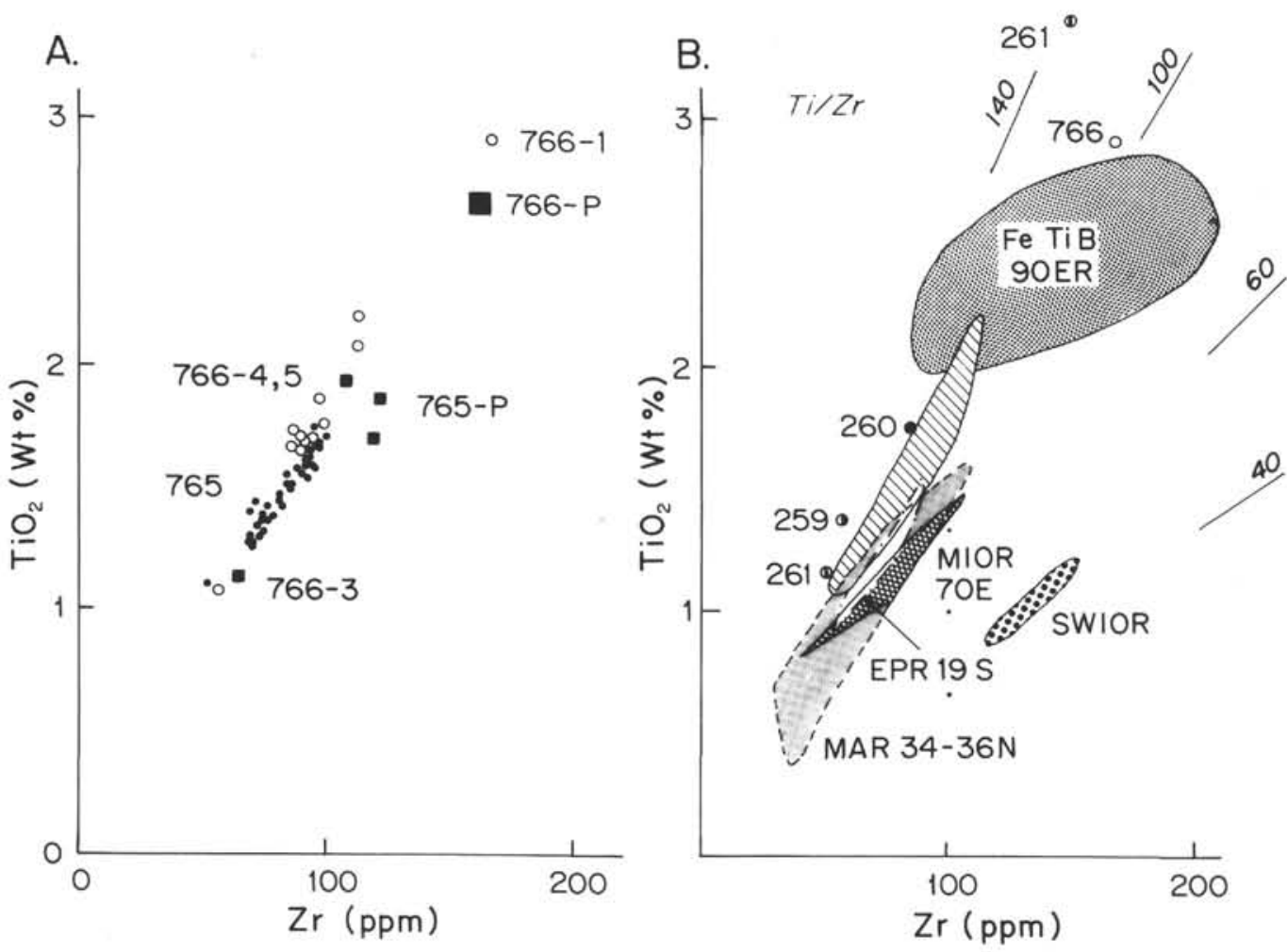

Figure 3. $\mathrm{TiO}_{2}-\mathrm{Zr}$ diagram for basaltic rocks at Sites 765 (dots) and 766 (circles) rocks (A) in comparison with representative basaltic rocks of the Indian Ocean floor (B). Unit 1 of Site 766, for example, is designated as "766-1," and pebbles are represented by "P." The basaltic rocks from Sites 259, 260, and 261 from the eastern Indian Ocean floor (Robinson and Whitford, 1974) also are plotted in B. MIOR $70^{\circ} \mathrm{E}$ and SWIOR represent Mid-Indian Ocean Ridge $70^{\circ} \mathrm{E}$ and Southwest Ridge, respectively (both after Price et al., 1986). FeTiB 90ER stands for Fe, Ti-basalt of Ninetyeast Ridge (Thompson et al., 1986), EPR 19 S for East Pacific Rise $19^{\circ}$ S (Erzinger, 1986), and MAR 34-36N for Mid-Atlantic Ridge $34^{\circ}-36^{\circ} \mathrm{N}$ (Wood et al., 1979). The numbers in italic are $\mathrm{Ti} / \mathrm{Zr}$ ratios.

primitive $\mathrm{N}-\mathrm{MORB}$ pebbles contain more $\mathrm{Na}_{2} \mathrm{O}$ than the differentiated basement basalt. This does not result from the more intense alteration of the pebbles, because fresh glass in another $\mathrm{N}$-MORB pebble is also more sodic than the glass that formed pillow margins of the Site 765 basement (Table 2). These features suggest that the pebble basalts were derived from a more enriched source than the basement basalts of Site 765 .
The glass samples from Site 765 basement resemble their crystalline counterparts (Tables 1 and 2). Among the five pillowmargin glass samples listed in Table 2, however, an unusual trend was observed. $\mathrm{TiO}_{2}$ (possibly also $\mathrm{Na}_{2} \mathrm{O}$ and $\mathrm{K}_{2} \mathrm{O}$ ) decreases with increasing $\mathrm{FeO}^{*} / \mathrm{MgO}$. This trend cannot be reconciled with general fractionation processes in ordinary terrestrial basaltic magmas. Nevertheless, the trend itself is due neither to analytical error

Table 2. Major-element chemistry of volcanic glass in pillow margins and of glass inclusions in plagioclase megacrysts.

\begin{tabular}{|c|c|c|c|c|c|c|c|c|c|}
\hline \multirow{4}{*}{$\begin{array}{l}\text { Sample: } \\
\text { Interval }(\mathrm{cm}) \text { : }\end{array}$} & \multicolumn{6}{|c|}{ Site 765 glass in pillow margins } & \multirow{2}{*}{\multicolumn{3}{|c|}{$\begin{array}{c}\text { Site } 765 \\
\text { glass inclusions in plagioclase } \\
\text { Basement }\end{array}$}} \\
\hline & \multirow{3}{*}{$\begin{array}{c}\frac{\text { Pebble }}{\text { B31X-1 }} \\
151-153\end{array}$} & \multicolumn{5}{|c|}{ Basement } & & & \\
\hline & & D24R-3 & D5R-1 & C63R-1 & C63R-2 & C63R-1 & C63R-3 & C63R-3 & C63R-2 \\
\hline & & $91-96$ & $48-50$ & $55-57$ & $13-15$ & $122-124$ & $76-81$ & $76-81$ & $61-63$ \\
\hline $\mathrm{SiO}_{2}$ & 50.46 & 50.17 & 51.42 & 51.55 & 51.98 & 51.05 & 50.92 & 51.38 & 51.51 \\
\hline $\mathrm{TiO}_{2}$ & 1.38 & 1.62 & 1.54 & 1.49 & 1.49 & 1.45 & 0.96 & 0.98 & 0.69 \\
\hline $\mathrm{Al}_{2} \mathrm{O}_{2}$ & 15.71 & 14.52 & 14.04 & 13.81 & 13.49 & 13.82 & 5.89 & 8.62 & 8.57 \\
\hline $\mathrm{Cr}_{2} \mathrm{O}_{3}$ & & 0.21 & & & & & 0.41 & 0.16 & 0.00 \\
\hline $\mathrm{FeO}^{\circ}$ & 9.29 & 11.23 & 11.04 & 11.85 & 11.94 & 12.96 & 13.32 & 12.05 & 12.72 \\
\hline $\mathrm{MnO}$ & 0.16 & 0.25 & 0.21 & 0.20 & 0.21 & 0.18 & 0.34 & 0.33 & 0.17 \\
\hline $\mathrm{MgO}$ & 7.98 & 7.75 & 7.10 & 6.85 & 6.74 & 6.82 & 15.23 & 12.93 & 11.93 \\
\hline $\mathrm{CaO}$ & 11.79 & 11.75 & 12.45 & 11.82 & 12.16 & 11.72 & 12.27 & 11.49 & 12.69 \\
\hline $\mathrm{Na}_{2} \mathrm{O}$ & 3.11 & 2.27 & 2.03 & 2.41 & 1.99 & 1.72 & 0.43 & 1.46 & 1.54 \\
\hline $\mathrm{K}_{2} \mathrm{O}$ & 0.12 & 0.23 & 0.00 & 0.02 & 0.00 & 0.03 & 0.24 & 0.60 & 0.19 \\
\hline Total & 100.00 & 100.00 & 100.00 & 100.00 & 100.00 & 100.00 & 100.00 & 100.00 & 100.00 \\
\hline $\mathrm{FeO}^{*} / \mathrm{MgO}$ & 1.16 & 1.45 & 1.55 & 1.73 & 1.77 & 1.90 & 0.87 & 0.93 & 1.07 \\
\hline
\end{tabular}

Note: The oxide values are normalized to total $100 \%$. 
nor to faulty sampling, because the identical trend can be observed among 39 crystalline basalt samples of Site 765 that were analyzed in the shipboard XRF laboratory (Fig. 4). The origin of this unusual trend will be discussed later.

The most primitive magma at Site 766 crystallized as Unit 3 . This is an N-MORB having $8 \mathrm{wt} \% \mathrm{MgO}, 300 \mathrm{ppm} \mathrm{Cr}_{2} \mathrm{O}_{3}$, and only $60 \mathrm{ppm}$ zirconium (Fig. 3A). The most evolved magma is that of Unit 1 , an $\mathrm{Fe}-\mathrm{Ti}$ basalt having $16 \mathrm{wt} \% \mathrm{FeO}^{*}$ and $3 \mathrm{wt} \% \mathrm{TiO}_{2}$. Units 4 and 5 are evolved $\mathrm{N}$-MORBs having $\mathrm{FeO}^{*}$ and $\mathrm{TiO}_{2}$ values averaging 14 and $1.8 \mathrm{wt} \%$, respectively (Table 1). Thus, each unit of Site 766 has unique petrographic and chemical characteristics, although all units exhibit systematic increase of $\mathrm{TiO}_{2}$ with increasing $\mathrm{FeO}^{*} / \mathrm{MgO}$ (Fig. 4). This contrasts with the trend observed at Site 765 . The $\mathrm{Ti} / \mathrm{Zr}$ ratio is uniform $(=120)$ throughout all units (Fig. 3A), suggesting that they are comagmatic. However, the REE geochemistry shown below indicates that Units 3 through 5 are derived from a more depleted source than that of Units 1 and 2 .

\section{Rare Earth Elements in Basaltic Rocks}

Two pebble samples, eight samples from Site 765 basement, and six samples from Site 766 were analyzed for REEs and Co, $\mathrm{Sc}$, and $\mathrm{Hf}$ by neutron activation methods using the Kyoto University reactor and a gamma-ray spectrometer having a $\mathrm{Ge}(\mathrm{Li})$ detector at the Radio-Isotope Center, Kanazawa University. The results are presented in Figure 5 and summarized in Table 1. The Leedey chondrite was used to normalize the REE values.

A pebble sample (123-765D-IR-1, 6-8 cm) shows a LREE-enriched pattern with a $(\mathrm{La} / \mathrm{Sm})_{\mathrm{N}}$ ratio (lanthanum/samarium ratio in chondrite-normalized values) of 1.63 , which is comparable to that of T- or even E-type MORBs. Another pebble sample (123765B-13R-1, 96-98 cm) shows an LREE-depleted pattern with a

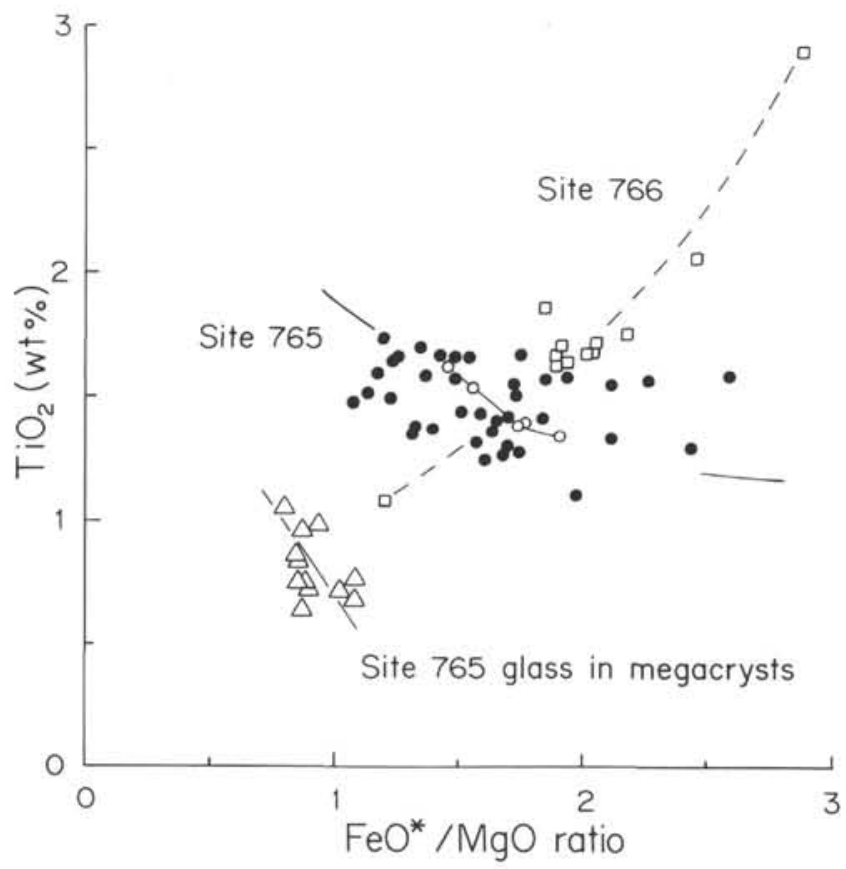

Figure $4 . \mathrm{TiO}_{2}-\mathrm{FeO}^{*} / \mathrm{MgO}$ relationship among Site 765 volcanic glasses (open circles) and crystalline basalts (solid circles). The two suites exhibit an identical, but unusual trend, i.e., $\mathrm{TiO}_{2}$ decreases with increasing $\mathrm{FeO}^{*} / \mathrm{MgO}$. Site 765 glass inclusions in plagioclase megacrysts (open triangles) and Site 766 basalts and diabase (open squares) also are shown for comparison (see text for discussion).

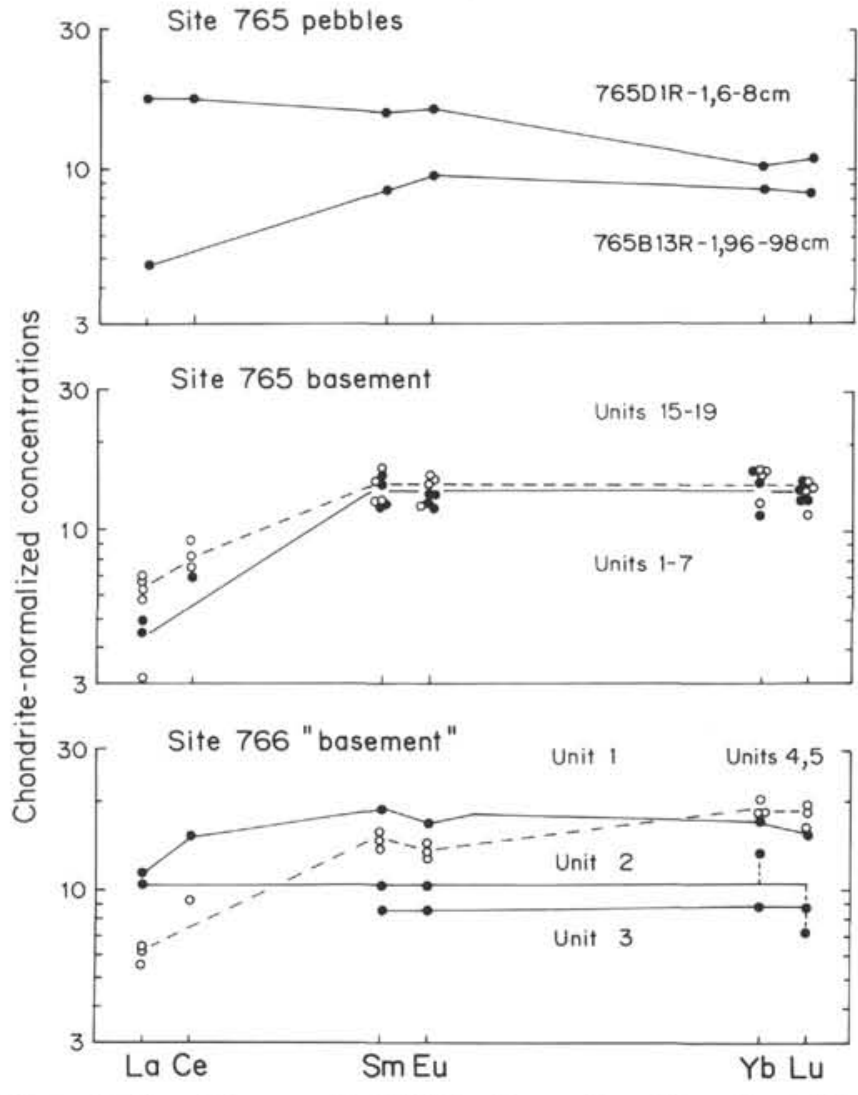

Figure 5. Chondrite-normalized REE patterns of basaltic rocks at Sites 765 and 766 . Leedey chondrite was used for normalization.

$(\mathrm{La} / \mathrm{Sm})_{\mathrm{N}}$ ratio at 0.55 , but it is not as LREE-depleted as the basement rocks of Site $765(<0.48)$.

The basement rocks of Site 765 invariably show the LREE-depleted patterns that are typical of N-MORBs. The REE distribution shows uniform concentration of HREE averaging 14 times chondrite and strong depletion in LREEs (Table 1), i.e., a typical pattern of N-MORBs. The N-MORBs of Site 765 are homogeneous in respect to the heavy and intermediate REEs, whose concentration ranges from 11 to 16 times that of chondrite. The light REEs, however, show significant stratigraphic change. The upper part of Site 765 basement is poor in La $(<1.9 \mathrm{ppm})$, while the lower part is relatively rich in $\mathrm{La}(>2.2 \mathrm{ppm})$. The $(\mathrm{La} / \mathrm{Sm})_{\mathrm{N}}$ ratio is 0.2 to 0.35 in the upper part and 0.42 to 0.48 in the lower part. This suggests that the upper, megacryst-bearing lavas originated from a more depleted source than the lower lavas.

The Site 766 "basement" also may be divided into two parts in terms of REE chemistry, i.e., the upper part showing a relatively flat pattern and the lower part with an LREE-depleted pattern. The porphyritic Fe-Ti basalt of Unit 1 shows a flat but slightly LREEdepleted pattern with a $(\mathrm{La} / \mathrm{Sm})_{\mathrm{N}}$ ratio of 0.69 . The HREE concentrations are 17 times those of chondrite. The aphyric basalt forming a small irregular sill or flow (Unit 2) is characterized by a fairly flat REE pattern, with a $(\mathrm{La} / \mathrm{Sm})_{N}$ ratio of 1.03 . In contrast, the lower, thick diabase intrusions of Units 4 and 5 show a strongly LREE-depleted pattern, with $(\mathrm{La} / \mathrm{Sm})_{\mathrm{N}}$ ratios between 0.30 and 0.38 . These rocks are fractionated, and their HREE contents approach 20 times those of chondrites. Unit 3 is the poorest in REE concentrations ( 9 times that of chondrite for HREE) in agreement with its primitive chemistry, such as low $\mathrm{FeO}^{*}$, high $\mathrm{Cr}$, and so forth. LREE content of Unit 3 was below the detection limit, suggesting an LREE-depleted pattern. 


\section{Strontium Isotope Chemistry}

Strontium isotope ratios of four basalt samples were measured at the Institute for Study of the Earth's Interior, Okayama University, under the instructions of $\mathrm{H}$. Kagami and with the assistance of T. Nakajima of Kanazawa University. Prior to this measurement, the powdered rock samples were leached with $6 \mathrm{~N}-\mathrm{HCl}$ to eliminate the effect of alteration minerals. The results are listed in Table 3.

The samples from Units 15 and 16 from the lower part of Hole $765 \mathrm{D}$ have ${ }^{87} \mathrm{Sr} /{ }^{86} \mathrm{Sr}$ ratios of 0.7028 and 0.7027 , respectively. The crystalline basalt of Unit 3 and the diabase of Unit 5 of Site 766 have ratios of 0.7030 and 0.7033 , respectively. As these basaltic rocks are poor in rubidium (10 ppm or less) and relatively rich in strontium $(80-100 \mathrm{ppm})$, the initial ${ }^{87} \mathrm{Sr} /{ }^{86} \mathrm{Sr}$ ratio $(\mathrm{SrI})$ at the time of their formation (Early Cretaceous) may have been lower than the present ratio by only 0.0001 or less. The present MIORB shows SrI values of between 0.7030 and 0.7033 in the vicinity of the triple point and 0.7027 in the other ridge segments. The measured SrI ratios of Site 765 and 766 basalts are within this range.

\section{Mineral Chemistry}

\section{Clinopyroxene}

$\mathrm{Fe}-\mathrm{Mg}-\mathrm{Ca}$ plots of pyroxenes in basalts from Sites 765 and 766 are presented in Figure 6, and representative pyroxene analyses are listed in Table 4. The clinopyroxene megacrysts from the Hole $765 \mathrm{C}$ basalts have a $\mathrm{Mg \#}$ as high as 87 . The clinopyroxene megacrysts from the upper basalt flows of Hole 765D are richer in $\mathrm{Fe}$ and have a $\mathrm{Mg} \#$ of between 71 and 81 , the range that roughly corresponds to that of the phenocrysts and groundmass clinopyroxenes from the Site 765 basalts. The brown dendritic clinopyroxene in the segregation vesicles is as Fe-rich as $\mathrm{Mg} \# 50$. The clinopyroxene in diabase exhibits strong chemical zoning. For example, the most primitive basalt forming Unit 3 of Site 766 bears clinopyroxene having a $\mathrm{Mg} \#$ of 85 in the core and 25 in the rim (Table 4). These clinopyroxenes follow a typical tholeiitic trend in the $\mathrm{Ca}-\mathrm{Mg}$-Fe diagram with relatively low $\mathrm{Ca}$ concentrations. In contrast, the clinopyroxenes in the basalt pebbles from the sedimentary section of Site 765 follow an alkali-basaltic trend, keeping high Ca concentrations through fractionation (Fig. 6).

The megacryst, phenocryst, and groundmass clinopyroxenes from basement at Sites 765 and 766 contain 2 to $4 \mathrm{wt} \% \mathrm{Al}_{2} \mathrm{O}_{3}$ and less than $1 \mathrm{wt} \% \mathrm{TiO}_{2}$, the range that corresponds to that of tholeiitic clinopyroxenes (Fig. 7). The differentiated clinopyroxenes in the segregation vesicles contain 5 to $6 \mathrm{wt} \% \mathrm{Al}_{2} \mathrm{O}_{3}$ and $2 \mathrm{wt} \% \mathrm{Ti}_{2} \mathrm{O}$. However, the clinopyroxenes from a few basalt pebbles contain more than $6 \mathrm{wt} \% \mathrm{Al}_{2} \mathrm{O}_{3}$ not withstanding their magnesian compositions. This again indicates an alkalic basalt affinity of the magma from which these pebbles were derived. Similar alkali-tholeiite transitional basalt with a Ca-rich clinopyroxene trend was reported from the Asal Rift in the Afar area (Bizouard and Richard, 1980).

\section{Orthopyroxene}

A single crystal of orthopyroxene occurs in a gabbroic fragment from the upper $50-\mathrm{m}$ section of the basement at Hole 765D. This is a pleochroic hypersthene with a $\mathrm{Mg} \#$ of 68 . The associated coarse-grained clinopyroxene $(\mathrm{Mg} \#=71)$ is as rich in $\mathrm{Fe}$ as the groundmass clinopyroxene $(\mathrm{Mg} \#=72$ ), and the associated coarsegrained plagioclase $\left(\mathrm{An}_{52}\right)$ is more sodic than the groundmass plagioclase $\left(\mathrm{An}_{66}\right)$.

\section{Plagioclase}

The plagioclase megacrysts from Hole $765 \mathrm{C}$ are as calcic as $\mathrm{An}_{86-91}$, while those from Hole $765 \mathrm{D}$ are as sodic as $\mathrm{An}_{52}$. The groundmass plagioclase of the basalt and diabase from Site 765 ranges from $\mathrm{An}_{60}$ to $\mathrm{An}_{70}$. The plagioclase segregation vesicles is about $\mathrm{An}_{86}$. The plagioclase phenocryst from Unit 1 of Site 766 is the most calcic at that site $\left(\mathrm{An}_{86}\right)$. The groundmass plagioclase in the most primitive basalt of Unit 3 is $\mathrm{An}_{73}$, and that of the diabase in Units 4 and 5 is $\mathrm{An}_{67}$ to $\mathrm{An}_{61}$. Although the coexisting clinopyroxene shows strong chemical zoning, the plagioclase in the diabase is almost homogeneous. The groundmass plagioclase from the basalt pebbles ranges from $\mathrm{An}_{54}$ to $\mathrm{An}_{67}$, and the phenocryst is as calcic as $\mathrm{An}_{75}$.

The $\mathrm{An}_{65-75}$ plagioclase in some pebble samples (123$765 \mathrm{D} 1 \mathrm{R}-1,6-8 \mathrm{~cm}$, and $123-766 \mathrm{~A}-9 \mathrm{R}-5,74-76 \mathrm{~cm}$ ) includes a $1.4 \mathrm{~mol} \%$ Or component and is distinctly more potassic than any plagioclase from the basement $(<0.4 \mathrm{~mol} \%$ Or $)$. This clearly indicates the $\mathrm{K}$-enriched nature of the magma, which formed basalt pebbles.

The relationship between the An content of the plagioclase and the $\mathrm{Mg} \#$ of the coexisting clinopyroxene is shown in Figure 8. The plagioclase-clinopyroxene pairs from Sites 765 and 766 plot mostly at the evolved end of the MORB field, while the megacryst pairs plot at the primitive end. The quenched pairs in the segregation vesicles are on the tholeiitic differentiation trend of the Bushveld Complex. The plagioclase-clinopyroxene pairs in the basalt pebbles have a more diverse composition, and some of them do not follow the general differentiation trend of the basement rocks.

\section{Glass Inclusions in Plagioclase Megacrysts}

These inclusions have a primitive chemistry (Table 2), with low $\mathrm{FeO}^{*} / \mathrm{MgO}(0.8-1.0)$, low $\mathrm{TiO}_{2}(0.7-1.0$ wt $\%)$, and high $\mathrm{CaO}$ (11-13 wt\%). These inclusions can coexist with $\mathrm{Fo}_{88}$ olivine, and they may be parental to the evolved N-MORBs at Sites 765 and 766 (Fig. 4). These inclusions are richer in $\mathrm{MgO}$ and $\mathrm{FeO}^{*}$ and poorer in $\mathrm{Al}_{2} \mathrm{O}_{3}$ than those reported from the Atlantic and Pacific oceans, but the $\mathrm{FeO}^{*} / \mathrm{MgO}$ ratios are roughly the same (Fig. 9). The difference may result from post-entrapment chemical changes. The crystallization of plagioclase at the wall of the liquid inclusion causes depletion of the plagioclase component ( $\mathrm{Al}, \mathrm{Ca}$ ) and enrichment of the plagioclase-incompatible elements (Fe, $\mathrm{Mg}$ ) in the residual liquid (Fig. 9). The high $\mathrm{Mg} \#$ of these glass inclusions suggests that the primary magma of the basement basalt at Site 765 was as primitive as that of Atlantic and Pacific N-MORBs.

\section{Spinel}

Spinel was found only in the primitive basalt pebbles at Site 765 as microphenocrysts or inclusions in olivine phenocrysts. These are ferric-poor chromian spinels with a $\mathrm{Cr} /(\mathrm{Al}+\mathrm{Cr})$ value of about 0.4 , which is typical of MORBs (Table 3 ).

\section{Magnetite}

Magnetite occurs as an interstitial mineral in diabase and includes as much as $23 \mathrm{wt} \% \mathrm{TiO}_{2}$ (Table 3).

\section{DISCUSSION}

\section{Origin of Negative Correlation between $\mathrm{TiO}_{2}$ and $\mathrm{FeO}^{*} / \mathrm{MgO}$}

The negative correlation of $\mathrm{TiO}_{2}$ with $\mathrm{FeO}^{*} / \mathrm{MgO}$ in the Site 765 basement (as shown in Fig. 4) was observed among both the 
Table 3. Representative pyroxene and spinel chemistry of basaltic rocks from Sites 765 and 766.

\begin{tabular}{|c|c|c|c|c|c|c|c|c|c|c|c|c|c|c|c|c|c|c|}
\hline \multirow{5}{*}{$\begin{array}{l}\text { Occurrence: } \\
\text { Core: } \\
\text { Interval (cm): } \\
\text { Mineral: }\end{array}$} & \multicolumn{10}{|c|}{ Site 765} & \multicolumn{7}{|c|}{ Site 766} & \\
\hline & \multirow{2}{*}{\multicolumn{3}{|c|}{ Basalt pebbles }} & \multirow{2}{*}{\multicolumn{3}{|c|}{$\begin{array}{c}\text { Megacrysts } \\
\text { in basalt flow }\end{array}$}} & \multirow{3}{*}{\multicolumn{2}{|c|}{$\begin{array}{c}\begin{array}{c}\text { Basalt } \\
\text { flow }\end{array} \\
\text { D23R-2 } \\
62-66\end{array}$}} & \multirow{3}{*}{\multicolumn{2}{|c|}{$\begin{array}{c}\begin{array}{c}\text { Diabase } \\
\text { sill(?) }\end{array} \\
\text { D24R-1 } \\
104-111 \\
\end{array}$}} & \multirow{4}{*}{$\begin{array}{c}\text { Basalt } \\
\text { pebble } \\
\text { A9R-5 } \\
74-76 \\
\text { ph-cpx }\end{array}$} & \multicolumn{6}{|c|}{ "Basement" } & \\
\hline & & & & & & & & & & & & \multirow{3}{*}{$\begin{array}{l}\text { Unit } 1 \\
\text { A49R-1 } \\
9-13 \\
\text { ph-cpx }\end{array}$} & \multirow{2}{*}{\multicolumn{2}{|c|}{$\begin{array}{c}\text { Unit } 3 \\
\text { A49R-4 } \\
106-108\end{array}$}} & \multirow{3}{*}{$\begin{array}{c}\text { Unit } 4 \\
\text { A50R-2 } \\
26-28 \\
\text { gm-cpx }\end{array}$} & \multirow{2}{*}{\multicolumn{3}{|c|}{$\begin{array}{c}\text { Unit } 5 \\
\text { A55R-2 } \\
74-76\end{array}$}} \\
\hline & \multirow{2}{*}{$\begin{array}{l}\text { C13R-2 } \\
39-43 \\
\text { spinel }\end{array}$} & \multirow{2}{*}{$\begin{array}{c}\text { C20R-1 } \\
6-7 \\
\text { gm-cpx }\end{array}$} & \multirow{2}{*}{$\begin{array}{c}\text { D1R-1 } \\
6-8 \\
\text { gm-cpx }\end{array}$} & \multirow{2}{*}{$\begin{array}{c}\text { C63R-4 } \\
68-73 \\
\text { cpx }\end{array}$} & \multicolumn{2}{|c|}{$\begin{array}{c}\text { D5R-3 } \\
51-57\end{array}$} & & & & & & & & & & & & \\
\hline & & & & & cpx & opx & gm-cpx & sv-cpx & cpx core & rim & & & cpx core & rim & & cpx core & rim & Ti-mt \\
\hline $\mathrm{SiO}_{2}$ & & 50.06 & 45.86 & 52.61 & 51.85 & 53.16 & 50.89 & 47.13 & 51.78 & 49.92 & 51.43 & 50.67 & 50.81 & 48.35 & 51.25 & 51.73 & 48.98 & \\
\hline $\mathrm{TiO}_{2}$ & 0.88 & 1.26 & 3.18 & 0.27 & 0.51 & 0.40 & 0.87 & 2.15 & 0.85 & 0.96 & 0.66 & 1.11 & 0.60 & 0.56 & 0.73 & 0.53 & 0.53 & 22.88 \\
\hline $\mathrm{Al}_{2} \mathrm{O}_{3}$ & 30.57 & 5.58 & 6.61 & 3.30 & 2.10 & 1.47 & 4.15 & 4.45 & 3.13 & 1.90 & 3.26 & 3.56 & 4.57 & 1.58 & 3.38 & 2.84 & 1.49 & 1.69 \\
\hline $\mathrm{Cr}_{2} \mathrm{O}_{3}$ & 32.36 & 0.28 & 0.31 & 0.40 & 0.18 & 0.04 & 0.33 & 0.05 & 0.60 & 0.15 & 1.00 & 0.57 & 1.00 & 0.00 & 0.72 & 0.59 & 0.07 & 0.15 \\
\hline $\mathrm{Fe}_{2} \mathrm{O}_{3}$ & 7.03 & & & & & & & & & & & & & & & & & 23.01 \\
\hline $\mathrm{FeO}$ & 13.27 & 7.70 & 11.19 & 5.09 & 10.92 & 19.04 & 9.08 & 19.05 & 7.03 & 20.27 & 5.94 & 9.26 & 5.71 & 28.43 & 8.24 & 8.05 & 27.48 & 51.31 \\
\hline $\mathrm{MnO}$ & & 0.13 & 0.18 & 0.01 & 0.10 & 0.43 & 0.19 & 0.29 & 0.13 & 0.60 & 0.02 & 0.28 & 0.31 & 0.62 & 0.27 & 0.29 & 0.78 & 0.39 \\
\hline $\mathrm{MgO}$ & 15.89 & 14.01 & 11.03 & 18.45 & 14.81 & 23.23 & 16.31 & 10.62 & 16.44 & 9.40 & 16.68 & 16.58 & 16.66 & 5.49 & 16.78 & 16.09 & 9.09 & 0.57 \\
\hline $\mathrm{CaO}$ & & 20.98 & 21.18 & 19.84 & 19.53 & 2.23 & 18.18 & 16.26 & 19.77 & 16.61 & 20.87 & 17.66 & 19.92 & 14.97 & 18.29 & 19.67 & 11.46 & \\
\hline $\mathrm{Na}_{2} \mathrm{O}$ & & & 0.46 & 0.02 & & & & 0.28 & 0.19 & 0.14 & 0.31 & 0.42 & 0.00 & 0.34 & 0.34 & 0.21 & 0.12 & \\
\hline Total & 100.00 & 100.00 & 100.00 & 100.00 & 100.00 & 100.00 & 100.00 & 100.00 & 100.00 & 100.00 & 100.00 & 100.00 & 100.00 & 100.00 & 100.00 & 100.00 & 100.00 & 100.00 \\
\hline \multicolumn{19}{|c|}{ Cation numbers on $0=6$ (pyroxenes) and $0=4$ (spinels) basis } \\
\hline $\mathrm{Si}$ & & 1.853 & 1.746 & 1.914 & 1.937 & 1.959 & 1.881 & 1.823 & 1.907 & 1.942 & 1.890 & 1.877 & 1.871 & 1.945 & 1.893 & 1.914 & 1.946 & \\
\hline $\mathrm{Ti}$ & 0.019 & 0.035 & 0.091 & 0.007 & 0.014 & 0.011 & 0.024 & 0.062 & 0.024 & 0.028 & 0.018 & 0.031 & 0.017 & 0.017 & 0.020 & 0.015 & 0.016 & 0.640 \\
\hline Al & 1.056 & 0.243 & 0.296 & 0.141 & 0.092 & 0.064 & 0.181 & 0.203 & 0.136 & 0.087 & 0.141 & 0.155 & 0.198 & 0.075 & 0.147 & 0.124 & 0.070 & 0.074 \\
\hline $\mathrm{Cr}$ & 0.750 & 0.008 & 0.009 & 0.011 & 0.005 & 0.001 & 0.010 & 0.002 & 0.017 & 0.005 & 0.029 & 0.017 & 0.029 & 0.000 & 0.021 & 0.017 & 0.002 & 0.005 \\
\hline $\mathrm{Fe}^{3+}$ & 0.155 & & & & & & & & & & & & & & & & & 0.643 \\
\hline $\mathrm{Fe}^{2+}$ & 0.325 & 0.238 & 0.356 & 0.155 & 0.341 & 0.586 & 0.281 & 0.616 & 0.216 & 0.659 & 0.182 & 0.287 & 0.176 & 0.956 & 0.254 & 0.249 & 0.913 & 1.595 \\
\hline $\mathrm{Mn}$ & & 0.004 & 0.006 & 0.000 & 0.003 & 0.013 & 0.006 & 0.009 & 0.004 & 0.020 & 0.001 & 0.009 & 0.010 & 0.021 & 0.008 & 0.009 & 0.026 & 0.012 \\
\hline $\mathrm{Mg}$ & 0.694 & 0.773 & 0.626 & 1.000 & 0.824 & 1.275 & 0.898 & 0.612 & 0.902 & 0.545 & 0.913 & 0.915 & 0.914 & 0.329 & 0.923 & 0.887 & 0.538 & 0.031 \\
\hline $\mathrm{Ca}$ & & 0.832 & 0.864 & 0.773 & 0.781 & 0.088 & 0.720 & 0.674 & 0.780 & 0.692 & 0.821 & 0.701 & 0.785 & 0.645 & 0.723 & 0.779 & 0.488 & \\
\hline $\mathrm{Na}$ & & & 0.034 & 0.001 & & & & 0.021 & 0.014 & 0.011 & 0.022 & 0.030 & 0.000 & 0.026 & 0.024 & 0.015 & 0.009 & \\
\hline Total & 2.999 & 3.986 & 4.028 & 4.002 & 3.997 & 3.997 & 4.001 & 4.022 & 4.000 & 3.989 & 4.017 & 4.022 & 4.000 & 4.014 & 4.013 & 4.009 & 4.008 & 3.000 \\
\hline $\mathrm{Mg \#}$ & 68.1 & 76.4 & 63.7 & 86.6 & 70.7 & 68.5 & 76.2 & 49.8 & 80.7 & 45.3 & 83.3 & 76.1 & 83.9 & 25.6 & 78.4 & 78.1 & 37.1 & 1.9 \\
\hline
\end{tabular}

Note: The oxide values are normalized to total $100 \%$. $\mathrm{Fe}_{2} \mathrm{O}_{3}$ of spinel was estimated so as to make cation total 3 on the 4 oxygen basis, assuming $\mathrm{R}^{2+} \mathrm{R}^{3+}{ }_{2} \mathrm{O}_{4}$ stoichiometry and TiR ${ }^{2+}-2 \mathrm{R}^{3+}$ exchange. Cpx $=$ clinopyroxene, opx $=$ orthopyroxene, $\mathrm{gm}=$ groundmass, $\mathrm{ph}=$ phenocryst, $\mathrm{sv}=$ segregation vesicle, $\mathrm{Ti}-\mathrm{mt}=$ titanomagnetite. 
Table 4. ${ }^{87} \mathrm{Sr} /{ }^{86} \mathrm{Sr}$ ratios of basaltic rocks from Sites 765 and 766.

\begin{tabular}{lrrlll}
\hline $\begin{array}{l}\text { Core, section, } \\
\text { interval }(\mathrm{cm})\end{array}$ & $\begin{array}{c}\text { Lith. } \\
\text { unit }\end{array}$ & $\begin{array}{c}{ }^{87} \mathrm{Sr} / 86 \mathrm{Sr} \\
(2 \sigma)\end{array}$ & \multicolumn{2}{c}{ Reference } & \\
\hline 123 - & & & & & \\
& & & & & \\
$765 \mathrm{D}-19 \mathrm{R}-1,72-73$ & 15 & $0.702831(20)$ & Intlab. STD & I \\
765D-21R-1, 133-135 & 16 & $0.702694(18)$ & Personal & $\# 56$ \\
$766 \mathrm{~A}-49 \mathrm{R}-5,44-50$ & 3 & $0.702976(22)$ & Personal & $\# 73$ \\
$766 \mathrm{~A}-55 \mathrm{R}-3,105-118$ & 5 & $0.703255(23)$ & Intlab STD & II \\
& & & & &
\end{tabular}

Note: Intlab STD = interlaboratory standard sample.

fresh glass and the crystalline rocks and cannot be the result of an alteration process such as selective $\mathrm{Mg}$ leaching from primitive (Ti-poor) basalt. The correlation may have resulted from fractional crystallization, mixing/assimilation, or partial melting, or by any combination of these processes.

The first interpretation is a classic fractional crystallization model. If the increase of $\mathrm{FeO}^{*} / \mathrm{MgO}$ is taken as a measure of the degree of fractionation, then $\mathrm{TiO}_{2}$ in the magma may have been buffered or removed by a $\mathrm{TiO}_{2}$-rich crystalline phase. However, $\mathrm{Na}_{2} \mathrm{O}$ and other incompatible elements regularly decrease with $\mathrm{TiO}_{2}$ (e.g., $\mathrm{Zr}$ in Fig. 3), and the crystalline phase(s) must have had higher concentrations of incompatible elements than the magma, a highly unrealistic assumption. Thus, the $\mathrm{FeO}^{*} / \mathrm{MgO}$ ratio must have decreased with fractionation. However, the fractionation of an Fe-rich and Ti-poor mineral, such as wüstite or $\mathrm{Fe}$ metal, is extremely unlikely under the normal oxygen fugacity in Earth's lithosphere. The fractionation of Ti-magnetite induces positive $\mathrm{TiO}_{2}-\mathrm{FeO}^{*} / \mathrm{MgO}$ correlations in the evolving melt. Moreover, the occurrence of $\mathrm{Fe}$ - and $\mathrm{Ti}$-rich segregation vesicles and the intense compositional zoning of groundmass pyroxene with $\mathrm{Fe}$-rich rims clearly indicate a normal $\mathrm{FeO} / \mathrm{MgO}$ increasing trend of the individual magma batch.

Another interpretation is that this correlation represents a mixing trend. One end-member may be N-MORB containing moderate $\mathrm{TiO}_{2}(1.7 \mathrm{wt} \%)$, low $\mathrm{FeO}^{*} / \mathrm{MgO}$ ratio (1.2), and relatively abundant incompatible elements. The other end-member may be an unusual magma having low $\mathrm{TiO}_{2}(1.2 \mathrm{wt} \%)$, high $\mathrm{FeO}^{*} / \mathrm{MgO}$ ratio (2.5), and extremely low abundances of the incompatible elements. This is a simple hypothesis, but how does the latter magma arise? This magma cannot be produced by fractionation of the former magma. A possible process is the remelting and assimilation of the mafic cumulates that form the lower part of the oceanic crust. These are depleted in incompatible elements and have a relatively high $\mathrm{FeO}^{*} / \mathrm{MgO}$ ratio. However, these cumulates are rich in plagioclase, and their remelting might produce a more aluminous magma, possibly with a positive europium anomaly, than was observed.

A third hypothesis assumes that the source mantle was heterogeneous in terms of the $\mathrm{FeO}^{*} / \mathrm{MgO}$ ratio and is relatively homogeneous in terms of incompatible elements. The $\mathrm{Fe}$ - and $\mathrm{Mg}$-rich parts may have been a few $100 \mathrm{~m}$ or smaller in size and may have formed an irregular patchwork. If the patchwork body is brought above the solidus, the $\mathrm{Fe}$-rich part (with a lower solidus temperature) undergoes higher degrees of melting than the Mg-rich part, and the incompatible elements are more diluted in the Fe-rich melt than in the Mg-rich melt. The unusual negative correlation among

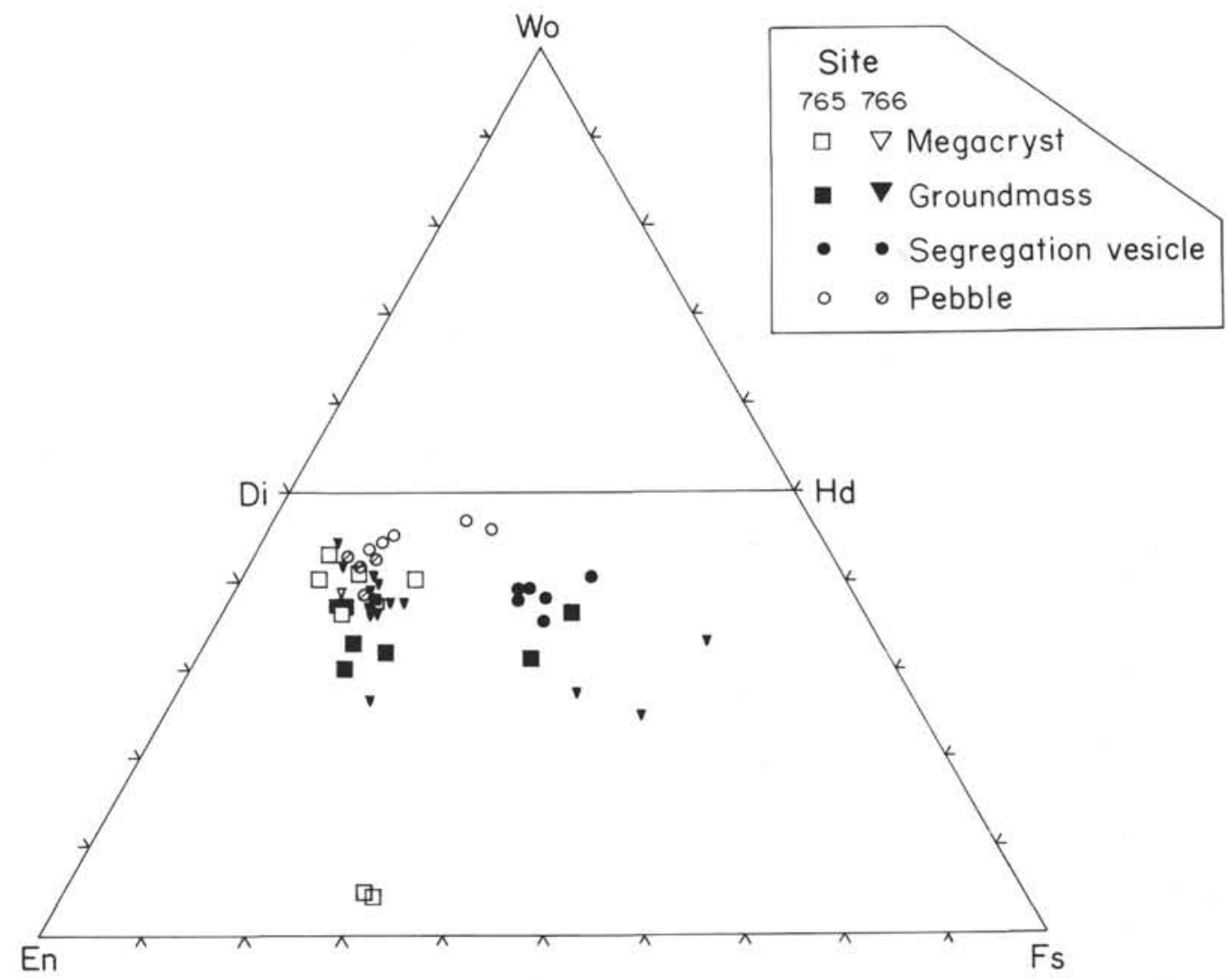

Figure 6. Ca-Mg-Fe diagram for pyroxenes from basaltic rocks of Sites 765 and 766 (see inset for symbols). The $\mathrm{Ca}, \mathrm{Mg}$, and $\mathrm{Fe}$ apices are marked by representative pyroxene end-members, wollastonite (Wo), enstatite (En), and ferrosilite (Fs), respectively. Diopside (Di) and hedenbergite (Hd) are also marked. 


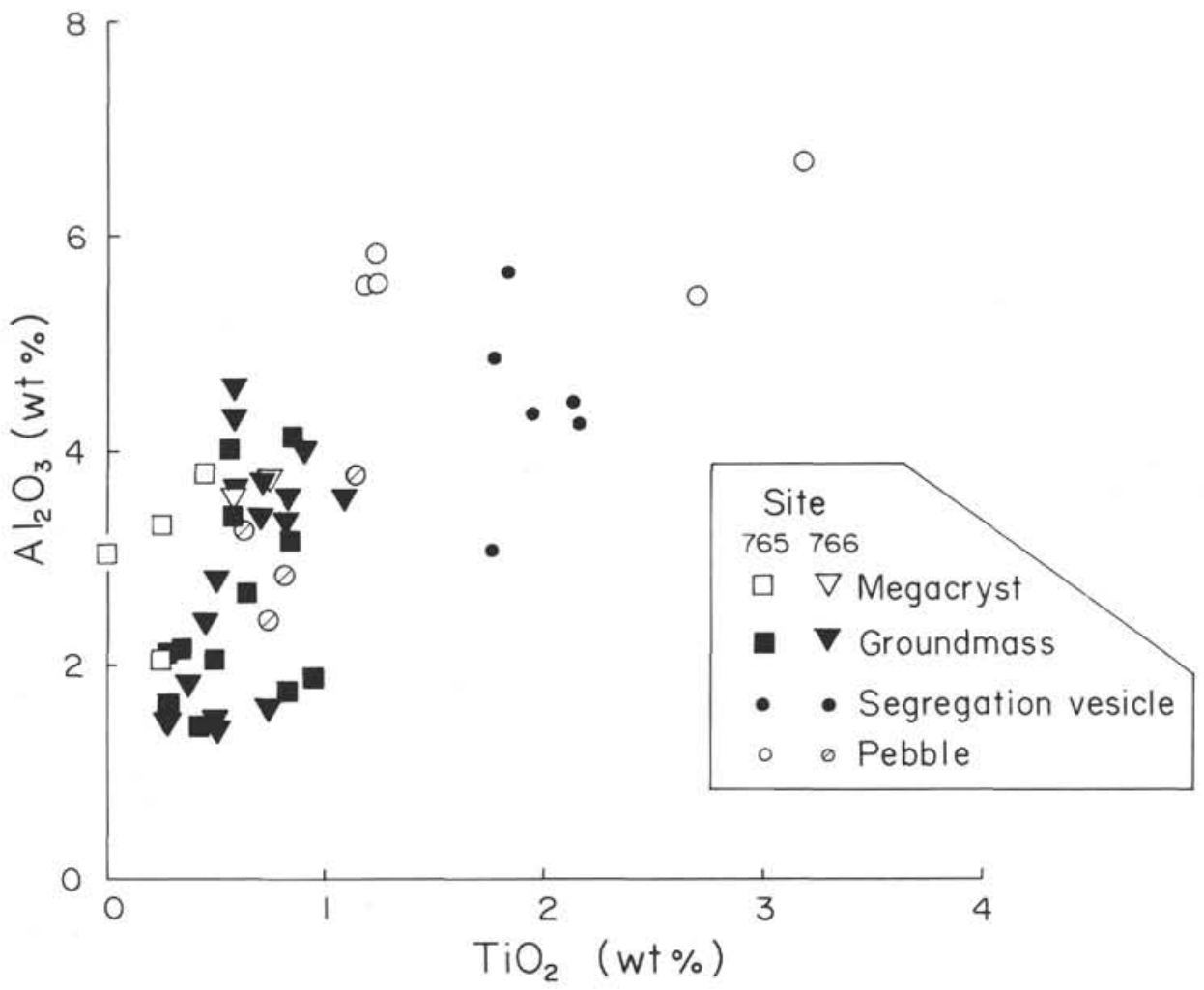

Figure 7. $\mathrm{TiO}_{2}-\mathrm{Al}_{2} \mathrm{O}_{3}$ diagram for clinopyroxenes from basaltic rocks at Sites 765 and 766 (see inset for symbols).

Site 765 basement basalts (Fig. 4) may have arisen through this process, provided that the degree of fractionation in the shallow depths is roughly uniform through all samples. The trend depicted in Figure 4 may thus represent a partial melting trend of the mantle, which was heterogeneous in terms of $\mathrm{FeO}^{*} / \mathrm{MgO}$ ratio. Note that the glass inclusions in plagioclase, a possible parental magma of Site 765 basalts, also indicate a negative trend (Fig. 4, triangles).

\section{Other Basaltic Rocks from the Indian Ocean Floor}

Both Sites 765 and 766 are underlain by the evolved NMORBs closely resembling each other. In the $\mathrm{Ti}-\mathrm{Zr}$ diagram (Fig. 3A), together they form a linear trend along a $\mathrm{Ti} / \mathrm{Zr}=120$ line, in spite of their different trends in the $\mathrm{TiO}_{2}-\mathrm{FeO} / \mathrm{MgO}$ diagram (Fig. 4). Clearly, their $\mathrm{Ti} / \mathrm{Zr}$ ratios are different from those of Southeast Indian Ridge basalts (about 90) and also from those of Southwest Indian Ridge basalts (about 45) (Fig. 3B). The $\mathrm{Ti} / \mathrm{Zr}$ ratios of basement basalts from DSDP Sites 259, 260, and 261 are as high as those of Sites 765 and 766 , suggesting that these high $\mathrm{Ti} / \mathrm{Zr}$ ratios are common features in the Cretaceous basaltic rocks forming the eastern Indian Ocean floor.

The $\mathrm{Ti} / \mathrm{Zr}$ ratio increases during advancing partial melting because of the differential incompatibility of $\mathrm{Ti}$ and $\mathrm{Zr}$, as $\mathrm{Zr}$ is more incompatible at the beginning of partial melting. In this context, the Early Cretaceous basement basalt of the eastern Indian Ocean floor may have formed through large degrees of partial melting beneath fast-spreading ridges. More differentiated basalt tends to be erupted from a faster spreading ridge, because large permanent magma chambers are present at a shallow level beneath the fast-spreading ridges. Such magma chambers are also consistent with the differentiated nature of the basalts at Sites 765 and 766.

\section{Implications for Early Cretaceous Rifting and Spreading}

The basaltic rocks obtained from the basement sections of Sites 765 and 766 are evolved N-MORBs that were derived from a depleted mantle source. However, the basaltic pebbles encountered in the turbidites of the overlying sedimentary section include primitive but relatively enriched $\mathrm{N}-\mathrm{MORBs}$ and alkalic EMORBs having $\mathrm{Ca}-$ - $\mathrm{Ti}$ - and $\mathrm{Al}$-rich clinopyroxene and slightly potassic plagioclase. Such an overall petrologic spectrum of the drilled sites resembles that of an area in the Afar Triangle-Bay of Aden Rift system, where temporal and spatial changes from pre-oceanic rift volcanism to oceanic ridge volcanism have been well-documented (Bizouard and Richard, 1980; Joron et al., 1980). For example, evolved, highly phyric, alkaline E-MORBs of the Asal Rift in the eastern Afar grade into slightly depleted T-MORBs of the Bay of Aden, and then into the typical NMORBs of Carlsberg Ridge. In this African-Arabic rift system, the degree of fractionation decreases with the progress of "oceanization." However, this trend was not obvious in the Early Cretaceous volcanism studied here, and the N-MORBs of the ocean floor are more differentiated than those near the continent.

\section{Magma Fractionation, Source Depletion, and Spreading Rate}

In general, both the apparent degree of fractionation (increasing $\mathrm{FeO}^{*} / \mathrm{MgO}, \mathrm{TiO}_{2}$, decreasing $\mathrm{Cr}$, etc.) and apparent degree of depletion $\left((\mathrm{La} / \mathrm{Sm})_{\mathrm{N}},{ }^{87} \mathrm{Sr} /{ }^{86} \mathrm{Sr}\right.$, etc. $)$ of MORBs increase with spreading rate in the Atlantic and Pacific oceans (Scheidegger, 1973; Holness and Richter, 1989). For example, average $(\mathrm{La} / \mathrm{Sm})_{\mathrm{N}}$ is about 1.25 at $3 \mathrm{~cm} / \mathrm{yr}$ and 0.6 at $18 \mathrm{~cm} / \mathrm{yr}$ (Holness and Richter, 1989). In this context, the evolved $\left(\mathrm{FeO}^{*} / \mathrm{MgO}=1.8\right)$ and depleted $\left((\mathrm{La} / \mathrm{Sm})_{\mathrm{N}}<0.5\right) \mathrm{N}-\mathrm{MORBs}$ of the drilled sites may 


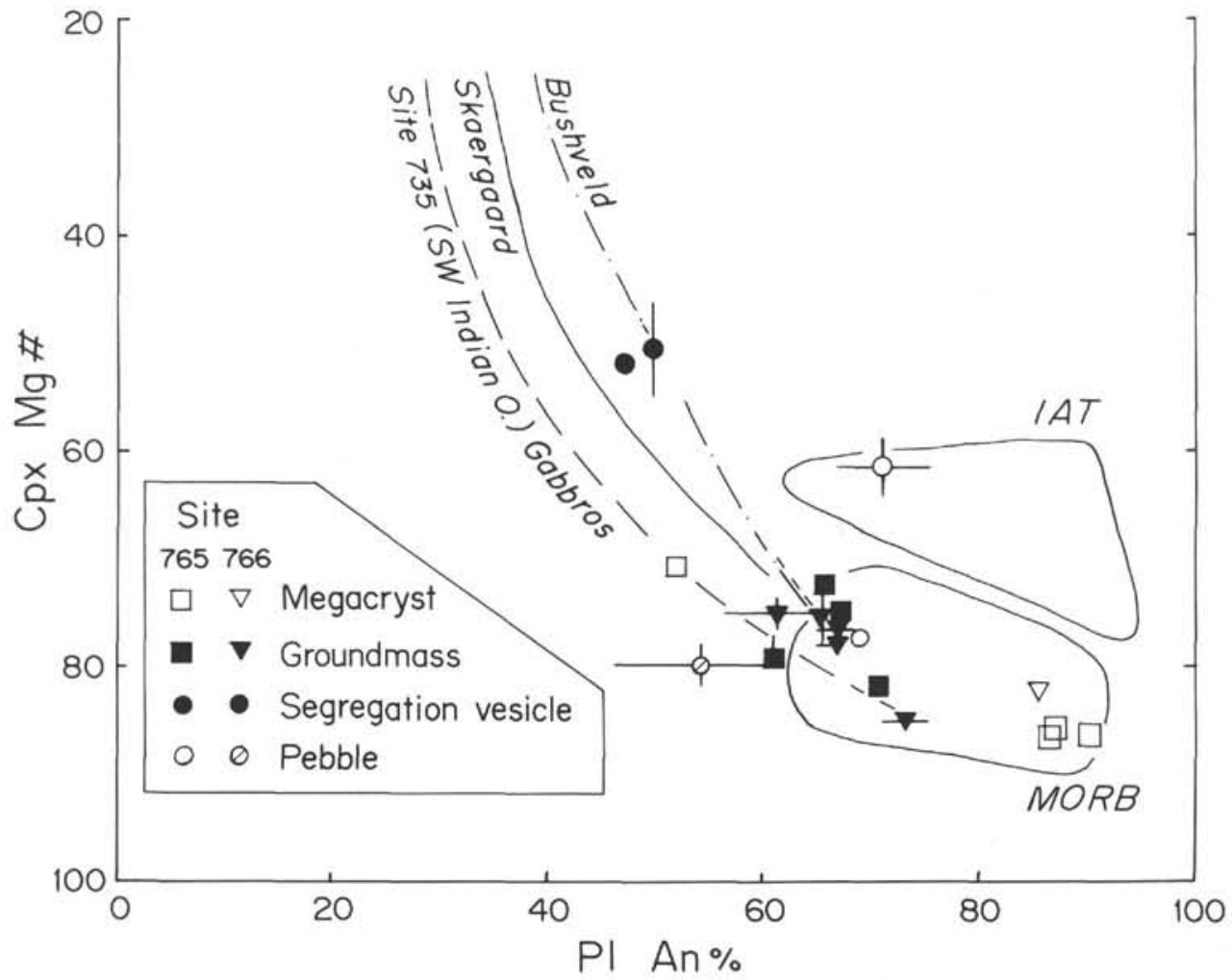

Figure 8 . The anorthite-Mg\# relationship between coexisting plagioclase $(\mathrm{PI})$ and clinopyroxene $(\mathrm{Cpx})$ in the basaltic rocks from Sites 765 and 766 (see inset for symbols). Island-arc tholeite (IAT) and MORB fields, as well as Bushveld and Skaergaard trends, are based on well-known miscellaneous sources. Site 735 data were kindly provided by K. Ozawa of the University of Tokyo.
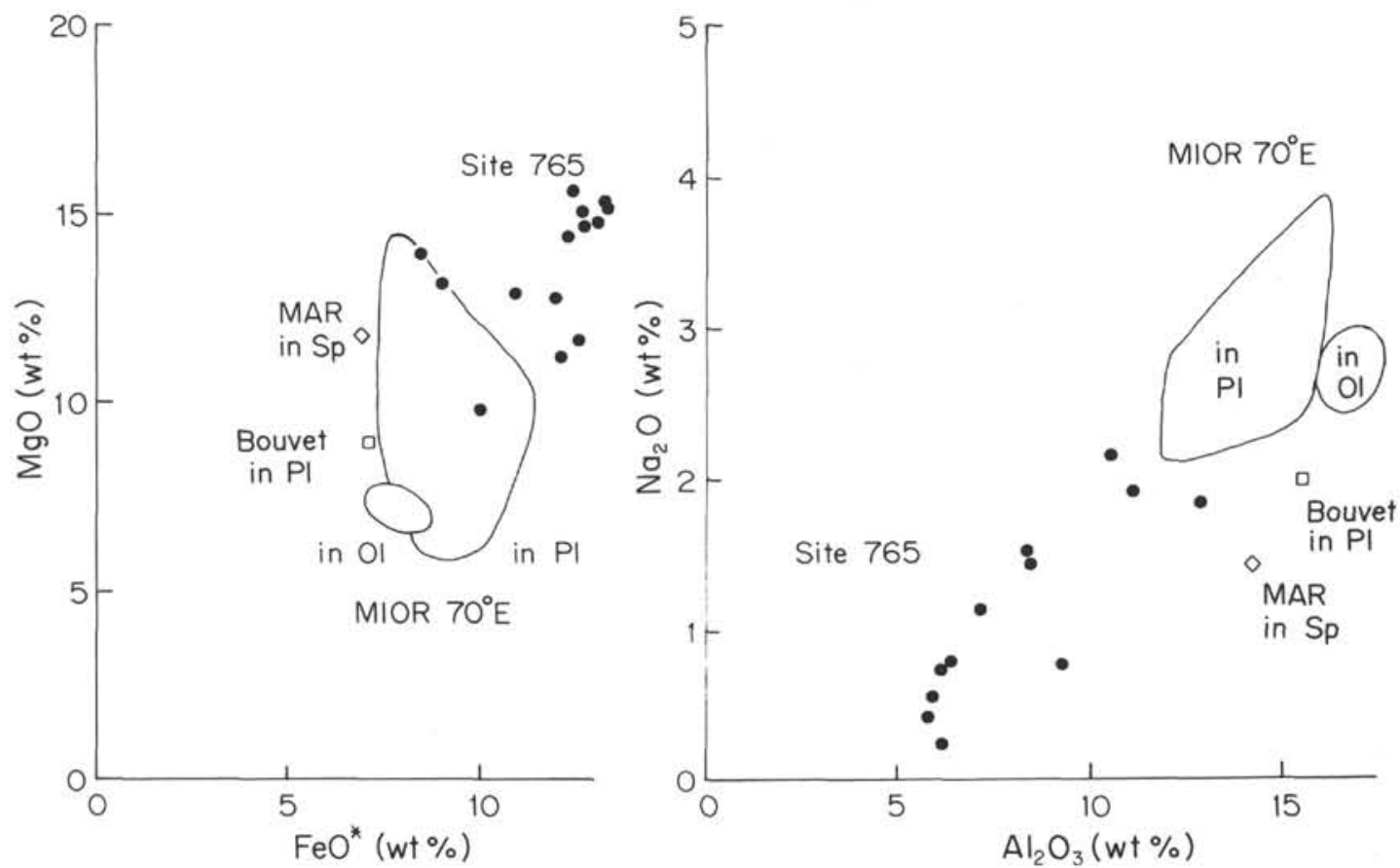

Figure 9. Chemical characteristics of the glass inclusions in the plagioclase megacrysts from the upper part of Site 765 basement. Data from Mid-Indian Ocean Ridge $70^{\circ} \mathrm{E}$, Mid-Atlantic Ridge, and Bouvet Island are from Price et al. (1986) and Donaldson and Brown (1977). Pl, Ol, and Sp represent plagioclase, olivine, and spinel, respectively. 
thus represent products of a fast-spreading ridge. However, this is not consistent with the relatively high $\mathrm{Sr}$ isotope ratio $(0.7027$ to 0.7033 : generally about 0.7025 at a fast-spreading ridge) and the actual spreading rate during the Early Cretaceous, estimated from magnetic anomalies on the Indian Ocean floor $(<6 \mathrm{~cm} / \mathrm{yr})$. These conflicting data prohibit simple interpretations with respect to spreading rate. Note that the Indian Ocean is generally excluded from the discussion about basalt chemistry-spreading rate correlations, possibly because of the presence of the Dupal anomaly.

\section{CONCLUSIONS}

1. Most basement basalts of Sites 765 and 766 are evolved $\mathrm{N}$-MORBs (average $\mathrm{FeO} / \mathrm{MgO}=1.8$ ) derived from a depleted source $\left((\mathrm{La} / \mathrm{Sm})_{\mathrm{N}}<0.5\right.$ and $\left.\mathrm{Ti} / \mathrm{Zr}=120\right)$. Their ${ }^{87} \mathrm{Sr} /{ }^{86} \mathrm{Sr}$ ratios are as low as those of the present MIORBs.

2 . The wide mineralogic variation of megacrysts and gabbroic fragments included in the basaltic rocks of Site 765 are evidence of the extensive fractionation taking place in a shallow magma chamber.

3.The high-magnesian basaltic glass inclusions (12-15 wt \% $\mathrm{MgO})$ trapped in plagioclase megacrysts $\left(\mathrm{An}_{90}\right)$ indicate the primitive nature of the parental magma.

4. Site 766 basalts follow a normal tholeiitic trend on the $\mathrm{TiO}_{2}-\mathrm{FeO}^{*} / \mathrm{MgO}$ diagram, but Site 765 basalts indicate an unusual trend in which $\mathrm{TiO}_{2}$ remains constant or even decreases with the increase of $\mathrm{FeO}^{*} / \mathrm{MgO}$. This unusual trend may be made up of a bundle of normal fractionation trends that began with parental magmas having variable $\mathrm{FeO}^{*} / \mathrm{MgO}$. This suggests fine-scale heterogeneity in the source mantle beneath Site 765 in terms of the $\mathrm{FeO}^{*} / \mathrm{MgO}$ ratio.

5. The basalt pebbles in the sedimentary sequence of Site 765 were derived from a slightly enriched source. These pebbles may have been transported from basement highs near the Australian passive margin and may represent earlier volcanism in the riftingdrifting history of the Australian continent.

\section{ACKNOWLEDGMENTS}

I thank H. Kagami of the Institute for Study of the Earth's Interior, Okayama University, for his kind instructions regarding $\mathrm{Sr}$ isotope analysis. I thank T. Nakajima of Kanazawa University (K.U.) for his assistance. I am grateful to H. Sakamoto and Y. Hamashima (K.U.) for their instructions regarding the neutron activation analysis. I thank $\mathrm{H}$. Sato of Hiroshima University for discussion. The reviews of J. Ludden, R. Hébert, and I. Gibson were helpful for improving the manuscript. K. Nakamura (K.U.) kindly prepared drawings and photographs. I also acknowledge the Grant-in-Aid for Young Scientists No. 01740472 offered by the Ministry of Education, Science and Culture (Monbusho), Japan.

\section{REFERENCES}

Anderson, A. T., Swihart, G. H., Atrioli, G., and Geiger, C. A., 1984. Segregation vesicles, gas filter-pressing, and igneous differentiation. J. Geol., 92:55-72.

Bizouard, H., and Richard, O., 1980. Etude de la transition dorsale océanique-rift émergé: golfe de Tadjoura, Asal, Afar central. Approche pétrographique et minéralogique. Bull. Soc. Géol. Fr., 22:935942.

Donaldson, C. H., and Brown, R. W., 1977. Refractory megacrysts and magnesium-rich melt Inclusions within spinel in oceanic tholelites: indications of magma mixing and parental magma composition. Earth Planet. Sci. Lett., 37:81-89.

Dupré, B., and Allègre, C. J., 1983. Pb-Sr isotope variation in Indian Ocean basalts and mixing phenomena. Nature, 303:81-89.

Erzinger, J., 1986. Basement geochemistry, Leg 92. In Leinen, M., Rea, D. K., et al. Init. Repts. DSDP, 92: Washington (U.S. Govt. Printing Office), 471-480.

Hart, S. R., 1984. A large scale isotopic anomaly in the Southern Hemisphere mantle. Nature, 309:753-757.

Holness, M. B., and Richter, F. M., 1989. Possible effects of spreading rate on MORB isotopic and rare earth composition arising from melting of a heterogeneous source. J. Geol., 97:247-260.

Joron, J.-L., Treuil, M., Jaffrezic, H., Villemant, B., and Richard, O., 1980. Géochimie des éléments en traces du magmatisme de l'Afar et de la mégastructure Mer rouge-Afar-golfe d'Aden. Implications pétrogénétique et géodynamiques. Bull. Soc. Géol. Fr., 22:945-957.

Ludden, J. N., Gradstein, F. M., et al., 1990. Proc. ODP, Init. Repts., 123: College Station, TX (Ocean Drilling Program).

Price, R. C., Kennedy, A. K., Riggs-Sneeringer, M., and Frey, F. A., 1986. Geochemistry of basalts from the Indian Ocean triple junction: implications for the generation and evolution of Indian Ocean ridge basalts. Earth Planet. Sci. Lett., 78:379-396.

Robinson, P. T., and Whitford, D. J., 1974. Basalts from the Eastern Indian Ocean, DSDP Leg 27. In Veevers, J. J., Heirtzler, J., et al., Init. Repts. DSDP, 27: Washington (U.S. Govt. Printing Office), 551-560.

Sato, H., 1979. Segregation vesicles and immiscible liquid droplets in ocean-floor basalt of Hole 396B, DSDP Leg 46. In Dmitriev, L., Heirtzler, J., et al, Init. Repts. DSDP, 46: Washington (U.S. Govt. Printing Office), 283-297.

Scheidegger, K. F., 1973. Temperatures and compositions of magmas ascending along Mid-Ocean Ridges. J. Geophys. Res., 78:3340-3355.

Thompson, G., Bryan, W. B., Frey, F. A., and Sung, C. M., 1974. Petrology and geochemistry of basalts and related rocks from Sites $214,215,216$, DSDP Leg 22, Indian Ocean. In von der Borch, C. C., and Sclater, J. G., et al., Init. Repts. DSDP, 22: Washington (U.S. Govt. Printing Office), 459-468.

Wood, D. A., Tarney, J., Varet, J., Saunders, A. D., Bougault, H., Joron, J.-L., Treuil, M., and Cann, J. R., 1979. Geochemistry of basalts drilled in the North Atlantic by IPOD Leg 49: implications for mantle heterogeneity. Earth Planet. Sci. Lett., 42:77-97.

Date of initial receipt: 24 May 1990

Date of acceptance: 6 May 1991

Ms 123B-160 


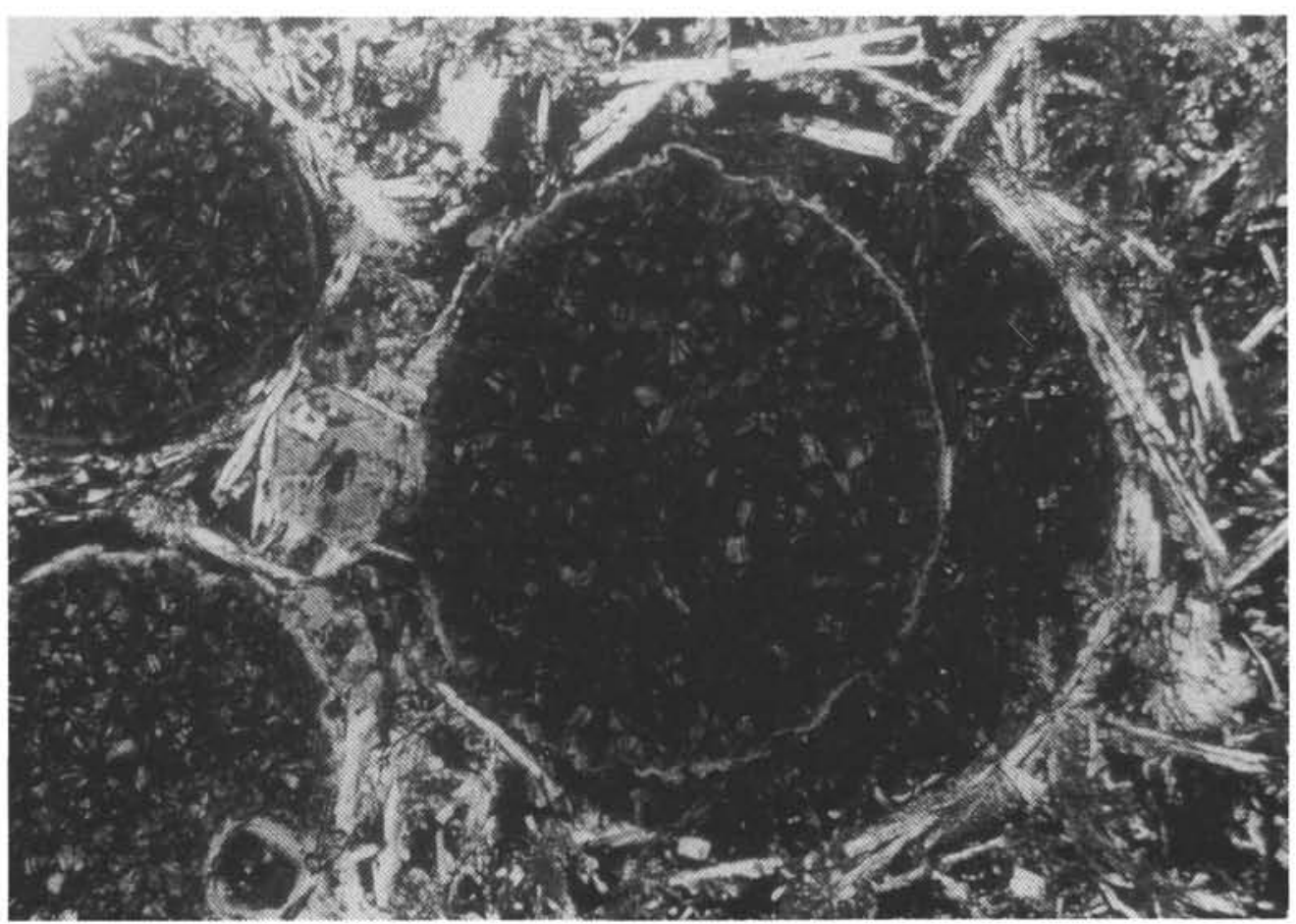

1

$1 \mathrm{~mm}$

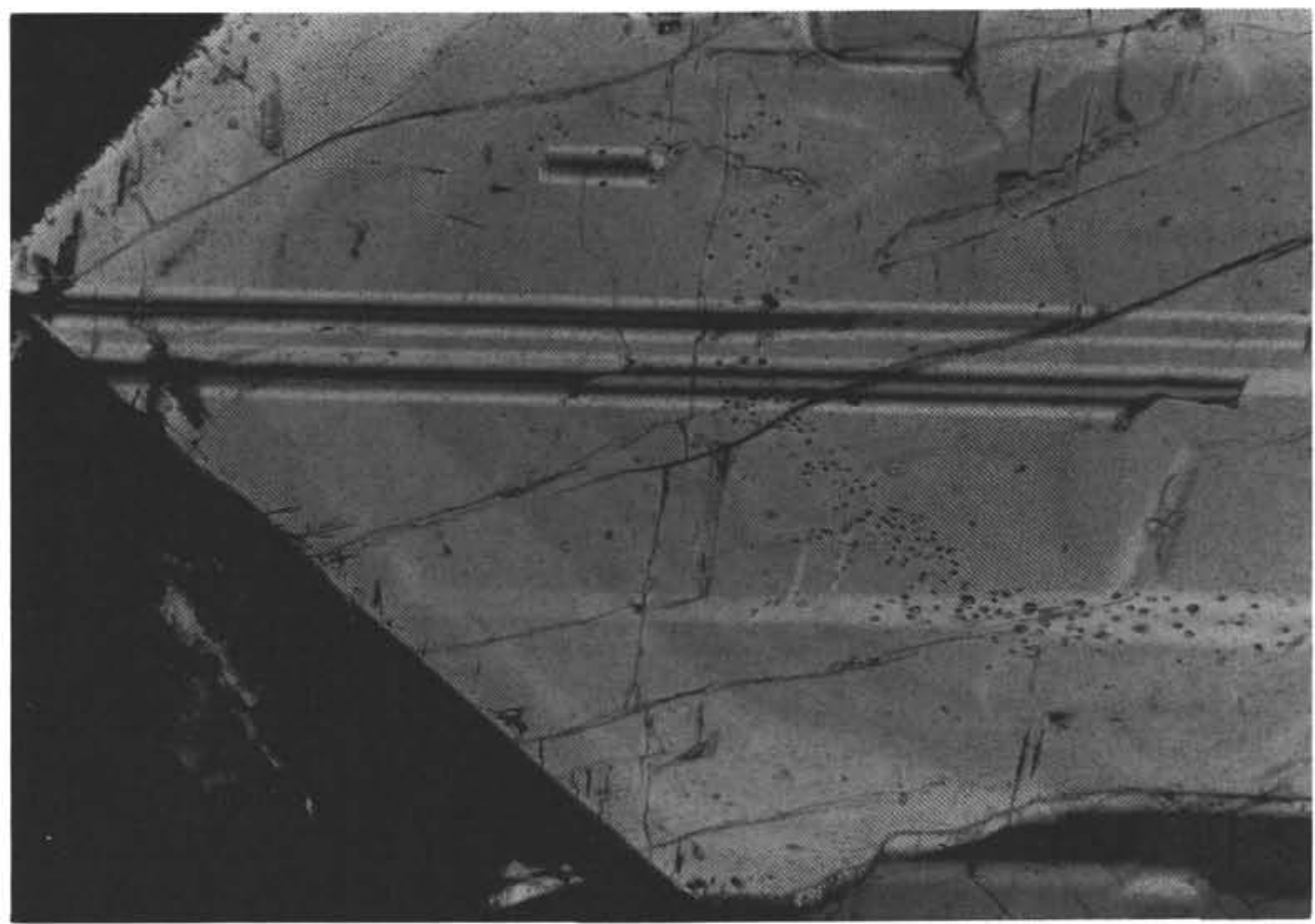

2

$1 \mathrm{~mm}$

Plate 1. 1. Thin-section photomicrograph of segregation vesicles in Sample 123-765D-23R-2, 64-66 cm; open nicols. The largest vesicle in center is $1.7 \mathrm{~mm}$ in diameter. The meniscus-shaped filling in the vesicle is made up of an aggregate of needle-shaped quench minerals, such as Fe-rich augite, ilmenite, and plagioclase, crystallized from the Fe-Ti basaltic liquid segregated inward from the outer solidifying MORB magma. The gas-filled space is now occupied by green clay minerals. 2. Thin-section photomicrograph of glass inclusions in a euhedral plagioclase megacryst in Sample 123-765C-63R-2, 61-63 cm; crossed nicols. The plagioclase is $2.3 \times 1.1 \mathrm{~mm}$ in size; this photograph covers only a zoned marginal part of the mineral. Tiny glass inclusions, 2 to $15 \mathrm{~mm}$ in diameter, are distributed in a concentrical zone passing the center of the photograph. Two dark horizontal bands in the middle are twins, and oblique irregular streaks are cracks. 